\title{
Review
}

\section{Mitochondrial Pathobiology in Parkinson's Disease and Amyotrophic Lateral Sclerosis}

\author{
Lee J. Martin* \\ Department of Pathology, Division of Neuropathology, and the Pathobiology Graduate Program, Department of \\ Neuroscience, Johns Hopkins University School of Medicine, Baltimore, MD, USA
}

Accepted 3 March 2010

\begin{abstract}
Parkinson's disease (PD) and amyotrophic lateral sclerosis (ALS) are the second and third most common human adult-onset neurodegenerative diseases, respectively, after Alzheimer's disease. They are characterized by prominent age-related neurodegeneration in selectively vulnerable neural systems. Some forms of PD and ALS are inherited, and genes causing these diseases have been identified. Morphological, biochemical, and genetic, as well as cell and animal model, studies reveal that mitochondria could have a role in this neurodegeneration. The functions and properties of mitochondria might render subsets of selectively vulnerable neurons intrinsically susceptible to cellular aging and stress and overlying genetic variations. In PD, mutations in putative mitochondrial proteins have been identified and mitochondrial DNA mutations have been found in neurons in the substantia nigra. In ALS, changes occur in mitochondrial respiratory chain enzymes and mitochondrial cell death proteins. Transgenic mouse models of human neurodegenerative disease are beginning to reveal possible principles governing the biology of selective neuronal vulnerability that implicate mitochondria and the mitochondrial permeability transition pore. This review will present how mitochondrial pathobiology might contribute to neurodegeneration in PD and ALS and could serve as a target for drug therapy.
\end{abstract}

Keywords: Adenine nucleotide translocator, apoptosis, cell death, cyclophilin D, excitotoxicity, mitochondrial permeability transition pore, motor neuron, ppif, voltage-dependent anion channel

\section{INTRODUCTION}

An exciting new understanding of mitochondrial biology has emerged over the past two decades from multiple disciplines that is likely to be very relevant to adult-onset neurodegenerative disorders. Mitochondria are multi-functional organelles [1]. In addition to their critical role in the production of ATP through the electron transport chain (Fig. 1), these organelles function in intracellular $\mathrm{Ca}^{2+}$ homeostasis, synthesis of steroid, heme and iron-sulfur clusters, and programmed cell death (PCD) [1-3]. Mitochondria are also sites of

${ }^{*}$ Correspondence to: Dr. Lee J. Martin, Johns Hopkins University School of Medicine, Department of Pathology, 558 Ross Building, 720 Rutland Avenue, Baltimore, MD 21205-2196, USA. Tel.: +1 410502 5170; Fax: +1 410955 9777; E-mail: martinl@jhmi.edu. formation of reactive oxygen species (ROS), including superoxide anion $\left(\mathrm{O}_{2}^{-}\right)[4]$ and the highly reactive hydroxyl radical $(\mathrm{OH})$ or its intermediates [5], and reactive nitrogen species, such as nitric oxide (NO) [1]. Mitochondria generate endogenous ROS as by-products of oxidative phosphorylation (Fig. 1) [3]. Because many mitochondrial proteins possess iron-sulfur clusters for oxidation-reduction reactions, and because mitochondrial DNA (mtDNA) lacks protective histones, these macromolecules are particularly vulnerable to ROS attack [3]. Electrons in the electron carriers, such as the unpaired electron of ubisemiquinone bound to coenzyme $\mathrm{Q}$ binding sites of complexes I, II, and III, can be donated directly to $\mathrm{O}_{2}$ to generate $\mathrm{O}_{2}^{-}$[3]. $\mathrm{O}_{2}^{-}$ does not easily pass through biological membranes and thus must be inactivated in compartments where it is generated [4]. The mitochondrial matrix enzyme man- 
ganese superoxide dismutase (MnSOD or SOD2), or copper/zinc SOD ( $\mathrm{Cu} / \mathrm{ZnSOD}$ or SOD1) in the mitochondrial intermembrane space and cytosol, convert $\mathrm{O}_{2}^{-}$to hydrogen peroxide $\left(\mathrm{H}_{2} \mathrm{O}_{2}\right)$ in the reaction $\mathrm{O}_{2}^{-}+$ $\mathrm{O}_{2}^{-}+2 \mathrm{H}^{+} \rightarrow \mathrm{H}_{2} \mathrm{O}_{2}+\mathrm{O}_{2}$ (Fig. 1) [4]. $\mathrm{H}_{2} \mathrm{O}_{2}$ is more stable than $\mathrm{O}_{2}^{-}$and can diffuse from mitochondria into the cytosol and nucleus. $\mathrm{H}_{2} \mathrm{O}_{2}$ is detoxified by glutathione peroxidase in mitochondria and the cytosol and by catalase in peroxisomes. In the presence of reduced transitional metals $\left(\mathrm{Fe}^{2+}\right), \mathrm{H}_{2} \mathrm{O}_{2}$ is catalyzed to $\mathrm{OH}$ [5]. $\mathrm{O}_{2}^{-}$can also react with $\mathrm{NO}$, which can be synthesized by three isoforms of nitric oxide synthase (NOS) enzymes [6], to form the potent nucleophile oxidant and nitrating agent peroxynitrite $\left(\mathrm{ONOO}^{-}\right)$(Fig. 1) [7]. $\mathrm{ONOO}^{-}$or products of $\mathrm{ONOO}^{-}$can damage proteins by nitration [13]. $\mathrm{ONOO}^{-}$is genotoxic directly to neurons by causing single- and double-strand breaks in DNA [8]. The NO produced in mitochondria [9] has direct actions in mitochondria. NO at nanomolar concentrations can inhibit rapidly and reversibly mitochondrial respiration by nitration or nitrosylation [10].

Mitochondria can participate in the etiology of human neuropathology. This involvement is found in disorders of acute interruptions in $\mathrm{O}_{2}$ and substrate delivery to the brain and bioenergetic failure as seen in cerebral ischemia and toxic exposures [1]. One example of a chronic neurodegenerative disease definitely related to mitochondria is optic atrophy type 1 (OPA1), a hereditary optic neuropathy, caused by mutations in the OPAI gene that encodes a mitochondrial dynamin-related GTPase that functions in maintenance of mitochondrial morphology, including fusion, and metabolism [11]. Mitochondria have a variety of properties and functions that might confer an intrinsic susceptibility of subsets of long-lived post-mitotic cells such as neurons to aging and stresses, including mutations and environmental toxins (Fig. 1). This review summarizes the evidence for mitochondrial involvement in Parkinson's disease (PD) and amyotrophic lateral sclerosis (ALS) and their animal and cell models. In this regard varying degrees of mitochondrial dysfunction and intrinsic mitochondrial-mediated cell death mechanisms could be critical determinants in the regulation of disease and neuronal cell death ranging from necrosis and apoptosis to autophagy [12-14]. Thus, targeting mitochondrial properties or entities, such as the mitochondrial permeability transition pore (mPTP) (Fig. 1) [15-18], could be important for developing new mechanismbased pharmacotherapies for these neurodegenerative diseases.

\section{PARKINSON'S DISEASE}

PD is a chronically progressive, age-related, incapacitating neurological disease in humans described first by James Parkinson in 1817. Estimates indicate that 4 to 6 million people have been diagnosed with PD. It affects about $2 \%$ of the population at some time in life. The greatest prevalence occurs in the USA, with between 100 and 250 cases per 100,000 [19], placing PD as the 2nd most common neurodegenerative disease with an adult onset (after Alzheimer's disease). Progressive resting tremor $(4-7 \mathrm{~Hz})$, rigidity, bradykinesia/akinesia, gait disturbance, and postural instability characterize PD clinically [20]. The disease progression is also associated with mood disturbances, dementia, sleep disturbances, and autonomic dysfunction [20]. There are currently no cures for PD. Medications and neurosurgery can relieve some of the symptoms.

A major neuropathological feature of PD is the degeneration and elimination of dopamine neurons in substantia nigra pars compacta (SNc) (Fig. 2) and in other brainstem regions which causes the movement disorder [21]. PD should however be regarded as a multiregional, multi-system neurodegenerative disorder in which the pathology appears in a regionally specific sequence, beginning in the dorsal motor nucleus of the vagus and olfactory bulbs and anterior nucleus followed by the locus coeruleus and then the SNc, at which time (when $\sim 50 \%$ of SNc neurons are lost) a clinical diagnosis of PD becomes possible [22]. The movement disorder in PD is thought to arise from reduced dopaminergic innervation of the striatum resulting from the loss of SNc neurons (Fig. 2) [22]. The effect of reduced dopaminergic input is over-activity of striatal neurons that project to and inhibit neurons in external globus pallidus (GPe), thus reducing the normal GPe inhibition of excitatory subthalamic neurons (Fig. 2) [23]. In addition, due to actions of dopamine on different dopamine receptor subtypes, there is also loss of normal dopaminergic excitation of striatal neurons that innervate internal GP (GPi) and SN reticularis, causing increased $\gamma$-aminobutyric acidergic inhibition of thalamic nuclei that drive activation of cerebral cortex (Fig. 2) [21]. PD can thus be explained functionally by over-activity of the subthalamic nucleus and GPi [21].

Another neuropathological feature of PD (Fig. 2) is the formation of eosinophilic proteinaceous intraneuronal or intra-glial inclusions, known as Lewy bodies (LBs), first described by Frederich Lewy in 1912. LBs are comprised of a dense core of filamentous material enshrouded by filaments $10-20 \mathrm{~nm}$ in diameter 


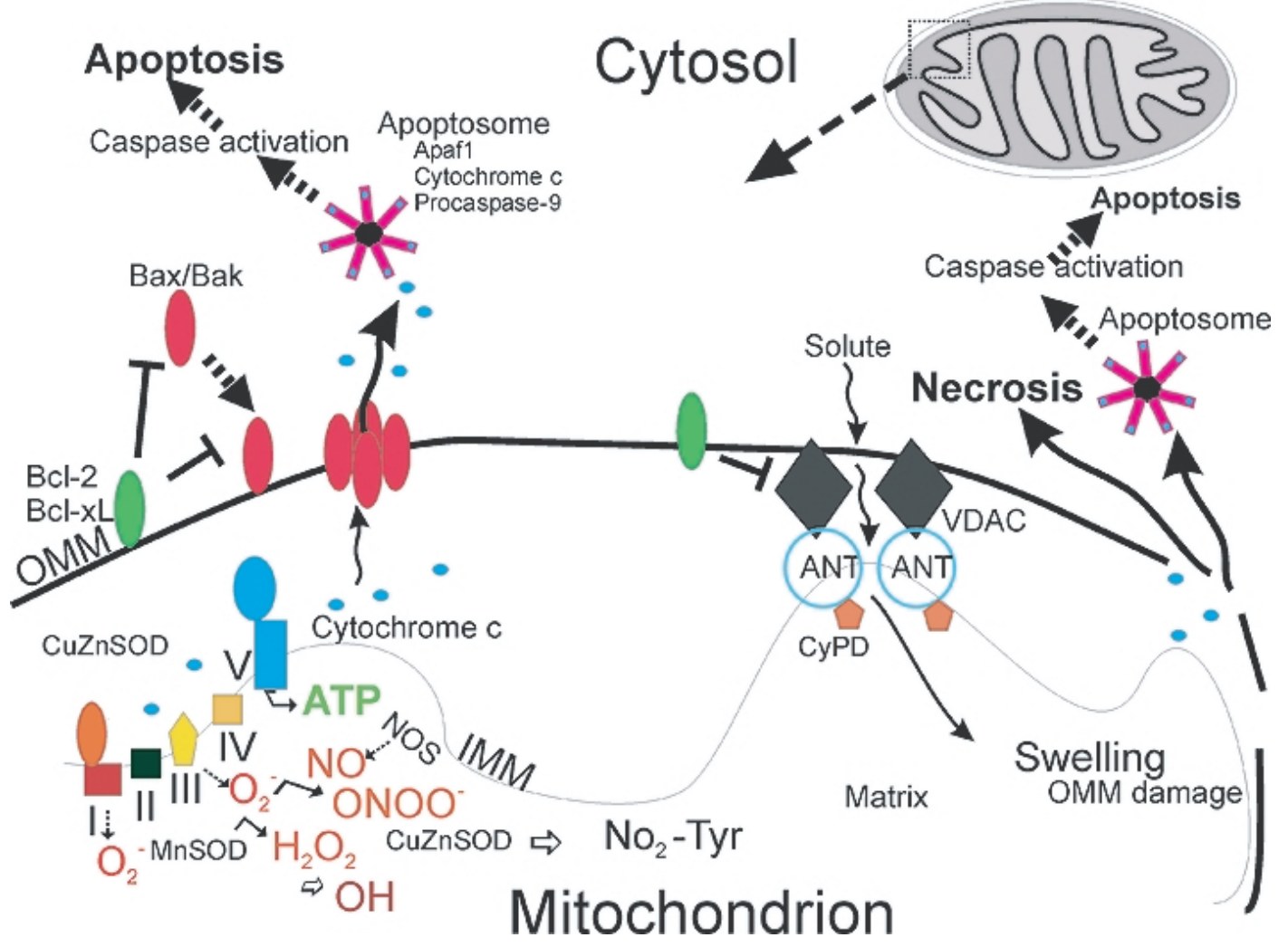

Fig. 1. Mitochondrial regulation of neuronal cell life and death in schematic representation. Mitochondria (upper right) are multi-functional organelles (see text). Oxygen- and proton pump-driven ATP production by the electron transport chain (lower left) is one function. The respiratory chain proteins (complex I-IV) establish an electrochemical gradient across the inner mitochondrial membrane (IMM) by extruding protons out of the matrix into the intermembrane space, thereby creating an energy gradient that drives the production on ATP by complex V (lower left). Superoxide $\left(\mathrm{O}_{2}^{-}\right)$is produced as a by-product in the process of electron transport and is converted to hydrogen peroxide $\left(\mathrm{H}_{2} \mathrm{O}_{2}\right)$ by $\mathrm{MnSOD}$ (or CuZnSOD in the intermembrane space). In pathological settings that can trigger cell aging and death, $\mathrm{H}_{2} \mathrm{O}_{2}$ can be converted to hydroxyl radical $(\mathrm{OH})$, or hydroxyl-like intermediates, and mitochondrial nitric oxide synthase (NOS) can produce nitric oxide (NO) that can combine with $\mathrm{O}_{2}^{-}$to form peroxynitrite $\left(\mathrm{ONOO}^{-}\right)$. $\mathrm{Cu} / \mathrm{ZnSOD}$ can use $\mathrm{ONOO}^{-}$to catalyze the nitration of mitochondrial protein tyrosine residues (bottom center) such as cyclophilin D (CyPD) and the adenine nucleotide translocator (ANT), which are core components of the mitochondrial permeability transition pore (another critical function of mitochondria). A third function of mitochondria is to regulate cell death. Bcl-2 family members regulate apoptosis by modulating the release of cytochrome $c$ from mitochondria into the cytosol. In the Bax/Bak1 channel model (left), Bax (Bcl-2-associated X protein) is a pro-apoptotic protein found mostly in the cytosol in healthy mammalian cells but, after specific cell death inducing stimuli, Bax undergoes a conformation shift and translocates to the outer mitochondrial membrane (OMM) where it inserts. Bak1 (Bcl-2-antagonist/killer 1) is a similar pro-apoptotic protein localized mostly to the mitochondrial outer membrane. Bax/Bak1 monomers physically interact to form oligomeric or heteromeric channels that are permeable to cytochrome $c$. The formation of these channels is blocked by Bcl-2 and Bcl- $x_{L}$ at multiple sites. Release cytochrome $c$ participates in the formation of the apoptosome, including apoptotic protease activating factor 1 (Apaf1) and procaspase-9, in the cytosol that drives the activation of caspase-3. Second mitochondria-derived activator of caspases (Smac)/direct IAP-binding protein with low pI (DIABLO) are released into the cytosol to inactivate the anti-apoptotic actions of inhibitor of apoptosis proteins that inhibit caspases (not shown). Another model (right) for mitochondrial directed cell death involves the permeability transition pore (PTP). The PTP is a transmembrane channel formed by the interaction of the ANT and the voltage-dependent anion channel (VDAC) at contact sites between the IMM and the OMM. CyPD, located in the matrix, can regulate the opening of the PTP by interacting with the ANT. Opening of the PTP induces matrix swelling and OMM rupture leading to release of cytochrome $c$ and other apoptogenic proteins. Certain Bcl-2 family members can modulate the activity of the PTP.

and are usually positive for ubiquitin and $\alpha$-synuclein ( $\alpha$-Syn) [24]. It is not clear whether LBs are related causally to the disease process.

The molecular pathogenesis of PD is still not understood. At least 2 forms of PD exist: idiopathic (sporadic) and heritable (familial) [25]. The majority of
PD cases are sporadic with no known genetic component. Epidemiological studies reveal several risk factors for developing idiopathic PD in addition to aging. Pesticides have now been linked convincingly to the development of PD [26]. Herbicides, well water (contaminated with pesticides), and industrial chemi- 

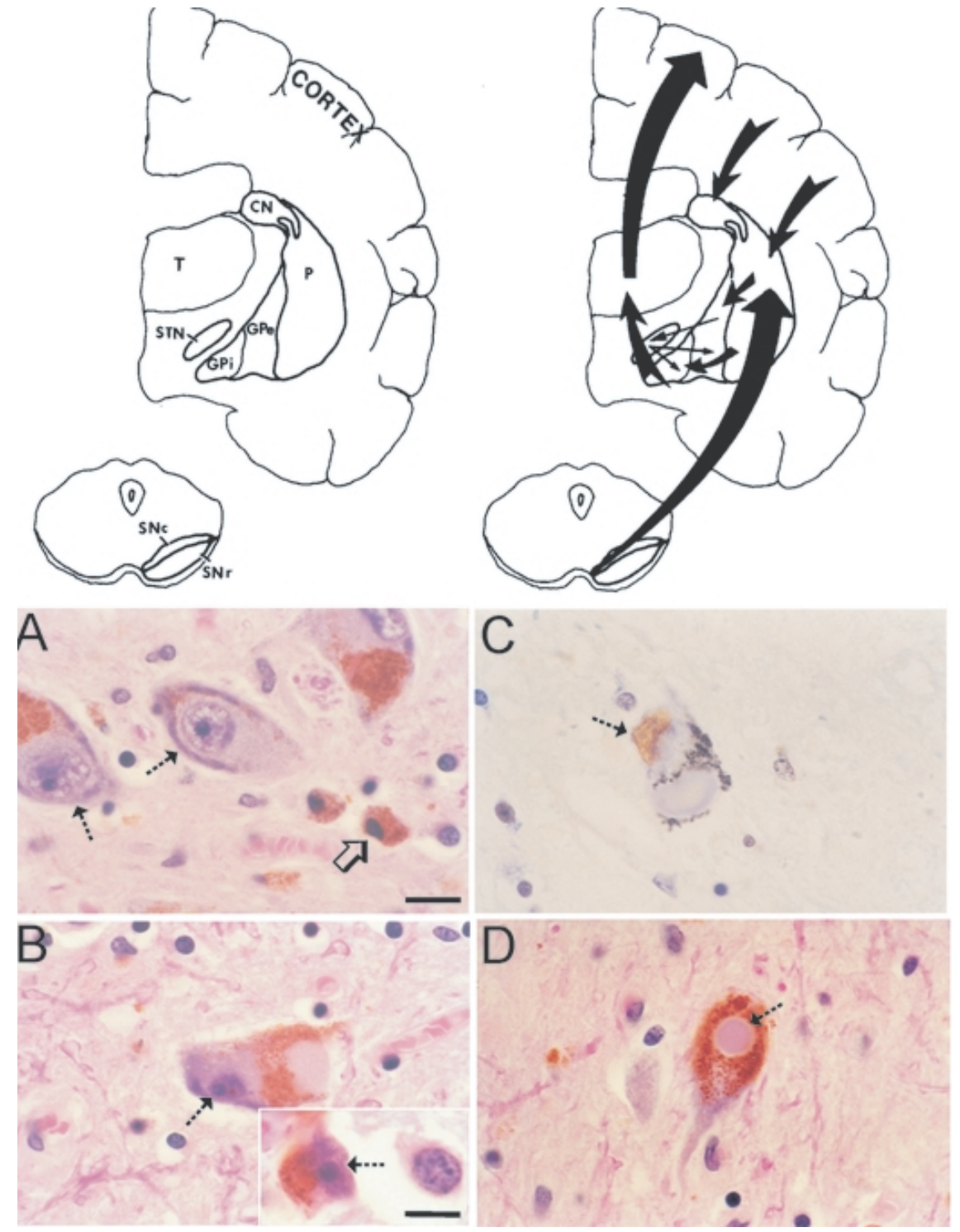

Fig. 2. Basal ganglia circuits in control of movement and SNc neuron degeneration in people with PD. The basal ganglia are comprised (top, left panel) of the caudate nucleus $(\mathrm{CN})$, putamen $(\mathrm{P})$, globus pallidus external (GPe) and internal (GPi) divisions, the subthalamic nucleus (STN), and the substantia nigra compact $(\mathrm{SNc})$ and reticular ( $\mathrm{SNr}$ ) divisions. The cerebral cortex and thalamus $(\mathrm{T})$, although not part of the basal ganglia, participate in the connectivity loops (right panel). The major excitatory input to the striatum (the caudate nucleus and putamen) is from the cerebral cortex (top, right panel). The striatum in turn projects to the globus pallidus and the substantia nigra reticular division. Striatal activity is modulated by an extensive dopaminergic input from the SNc. The major output of the basal ganglia is directed toward the thalamus, originating from GPi and from the substantia nigra reticular division (not shown). The thalamic projection to the cerebral cortex (premotor and supplementary motor areas) drives the activity of motor cortex which executes somatic movements. Degeneration of SNc neurons in human PD. A, B) Hematoxylin-eosin (H\&E) staining shows that the degeneration of pigmented SNc neurons is characterized by chromatolysis (A, hatched arrows), nuclear condensation (B, hatched arrow), and severe soma attrition (B, inset hatched arrow). The neuronal chromatolysis (in $\mathrm{A}$ ) is indicated by the eccentrically placed nucleus, pale cytoplasm, and peripheral margination of the Nissl substance. Glial/macrophage-like cells (A, open arrow) are laden with phagocytosed cellular debris. The nucleus of SNc neurons undergoes considerable condensation (B, hatched arrow) while the Nissl substance dissipates, but before appreciable somal shrinkage. The cell body of SNc neurons then becomes attritional (B, inset, hatched arrow), resulting in residual neurons that are $~ 10-20 \%$ their normal size. The cell shown is an atrophic neuron, rather than a debris-laden macrophage, because of the presence of a condensed nucleus with a single prominent nucleolus. This degeneration pattern could be indicative of autophagy. C) The nuclear condensation stage of pigmented SNc neuron degeneration is characterized by the appearance of DNA double-strand breaks as detected by TUNEL (arrow, brown staining). D) Subsets of SNc neurons accumulate Lewy bodies (arrow). Scale bars: A, $20 \mu \mathrm{m}$ (same for B,C,D); B inset, $6 \mu \mathrm{m}$. 
cals are possible neurotoxic agents related to the development of PD [25]. It has been believed for over a decade that mitochondrial dysfunction is related to the pathogenesis of PD. Complex I activity (NAPH dehydrogenase), comprised of 45 separate polypeptide subunits, was found to be reduced in the SN and platelets of PD cases, with changes in skeletal muscle being contentious [25]. When drug abusers exposed to 1-methyl-4-phenyl-1,2,3,4-tetrahydropyridine (MPTP) presented with PD and then it was discovered that the active metabolite of MPTP, the 1-methyl4-phenylpyridinium ion $\left(\mathrm{MPP}^{+}\right)$is a complex I inhibitor [25], the role for mitochondrial involvement in PD etiology became more compelling. Complex I inhibitors, notably rotenone, cause damage to dopaminergic neurons and are the basis of several animal and cell models [27].

\section{MUTANT GENES THAT CAUSE SOME FORMS OF PD}

About $5-10 \%$ of people with PD have familial patterns of inheritance [25]. Several genes have been implicated in Mendelian forms of PD. Gene mutations with autosomal dominant or autosomal recessive inheritance patterns have been identified in familial forms of PD (Table 1). PD-linked mutations occur in the genes encoding $\alpha$-Syn, Parkin, ubiquitin carboxy-terminal hydrolyase-L1 (UCHL1), phosphatase and tensin homolog (PTEN)-induced putative kinase-1 (PINK1), DJ-1, and leucine-rich repeat kinase-2 (LRRK2). In rare autosomal dominant inherited forms of $\mathrm{PD}$, missense mutations in the $\alpha$-syn gene (PARK1) result in amino acid substitutions Ala-53 $\rightarrow$ Thr, Ala-30 $\rightarrow$ Pro, Glu-46 $\rightarrow$ Lys; in addition, duplication and triplication mutations in the $\alpha$-syn gene (PARK4) have been found [28,29]. A missense mutation in the $U C H L 1$ gene (PARK5), resulting in the amino acid substitution Ile$93 \rightarrow$ Met, can also cause very rare autosomal dominant PD [30]. Loss-of-function mutations due to large deletions and truncations and also missense or nonsense mutations in parkin (PARK2), PINK1 (PARK6), and $D J-1$ (PARK7) are the cause of autosomal-recessive inheritance of PD [31-34]. Several missense mutations in the LRRK2 gene (PARK8) have been found, resulting in amino acid substitutions Tyr-1654 $\rightarrow$ Cys, Arg-1396 $\rightarrow$ Gly, Tyr-1699 $\rightarrow$ Cys, Arg-1441 $\rightarrow$ Cys, Ile$1122 \rightarrow$ Val, Ile-2020 $\rightarrow$ Thr, that cause more commonly occurring autosomal dominant PD and possibly 'sporadic' $\mathrm{PD}[35,36]$. PARK 9 has been ascribed to a dele- tion mutation (cytosine at nucleotide position 3057) or guanine-to-adenine transition at a splice site of exon 13 in the ATP13A2 gene that encodes a predominantly neuronal P-type lysosomal ATPase [37]. Potential lysosomal dysfunction related to ATP13A2 mutant proteins might tie into PD etiology through abnormalities in autophagy. Mutations of genes at other PD loci are more controversial (Table 1).

$\alpha-S y n$

$\alpha$-Syn is a relatively small (140 amino acids) very abundant protein $(\sim 1 \%$ of total protein) found in cells throughout the nervous system and is particularly enriched in neuronal axon terminals [38-40]. The functions of $\alpha$-Syn are not well known; however, growing evidence shows a role for $\alpha$-Syn in neurotransmitter release. Mice without $\alpha$-Syn have no overt phenotype [41], but neurons deficient in $\alpha$-Syn have a reduction in the reserve pool of synaptic vesicles needed for responses to tetanic stimulation and show defective mobilization of dopamine and glutamate [40,42]. Without $\alpha$-Syn neurons have impaired long-lasting enhancement of evoked and miniature neurotransmitter release [43]. $\alpha$-Syn is highly mobile and rapidly dissociates from synaptic vesicle membranes after fusion in response to neuronal activity [44]. It appears that $\alpha$-Syn acts as a molecular chaperone to assist cysteinestring protein- $\alpha$ in the folding and refolding of SNARE synaptic proteins [45].

$\alpha-$ Syn is a soluble monomeric protein that can associate with mitochondrial membranes [46]. It can be induced to polymerize into insoluble fibrils due to a conformational change from an $\alpha$-helical coil to a $\beta$ pleated sheet [47]. $\alpha$-Syn is a major structural component of LBs, forming the $\sim 10 \mathrm{~nm}$ fibrils, but in most neurodegenerative diseases, LBs are associated with accumulation of wild-type, not mutant, $\alpha$-Syn [24]. $\alpha$-Syn mutations cause increased levels of protofibrils, possibly being the more toxic form of the protein [48]. $\alpha$-Syn protofibrils might also be toxic by making membranes of cells more porous [49]. Overexpression of human wild-type or mutant $\alpha$-Syn in cultured cells elevates the generation of intracellular ROS [50,51] and causes mitochondrial deficits [50]; moreover, expression of mutant $\alpha$-Syn increases cytotoxicity to dopamine oxidation products [52]. Aggregation of wild-type and mutated $\alpha$-Syn is associated with enhanced cell death in cultured cells [53]. Nitration of $\alpha$-Syn, signifying the presence of potent reactive nitrogen species such as $\mathrm{ONOO}^{-}$or its free radical 
Table 1

Mutant Genes Linked to Familial PD

\begin{tabular}{llcl}
\hline Locus & Inheritance & Gene & Protein nme/ fnction \\
\hline PARK1/4q21 & autosomal dominant & $\alpha-$ syn & $\alpha-$ Syn/presynaptic maintenance? \\
PARK2/6q25.2-27 & autosomal recessive & parkin & Parkin/ubiquitin E3 ligase \\
PARK3/2p13 & autosomal dominant & $?$ & $?$ \\
PARK4/4p15 & autosomal dominant & $\alpha-$ syn & $\alpha$-Syn/presynaptic maintenance? \\
PARK5/4p14 & autosomal dominant & UCHL1 & UCHL1/polyubiquitin hydrolase \\
PARK6/1p36 & autosomal recessive & PINK1 & $\begin{array}{l}\text { PTEN-induced putative kinase-1/mitochondrial } \\
\text { protein kinase }\end{array}$ \\
& & & DJ-1/mitochondrial antioxidant, chaperone \\
PARK7/1p36.33-36-12 & autosomal recessive & DJ-1 & Donase \\
PARK8/12q12 & autosomal dominant & LRRK2 & Dardarin/multifunctional kinase/GTPase \\
PARK9/1p36 & autosomal recessive & ATP13A2 & Lysosomal type 5 P-ATPase \\
PARK10/1p32 & & $?$ & $?$ \\
PARK11/2q36-37 & autosomal dominant & GIGYF2? & Grb10-interacting GYP protein 2, modulates ty- \\
& & & rosine kinase receptor signaling, including IGF-1 \\
PARK12/Xq21-q25 & X-linked & $?$ & $?$ \\
PARK13/2p12 & autosomal recessive & Omi/HtrA2 & Omi/HtrA2, mitochondrial serine peptidase, in- \\
& susceptibility factor & & hibitor of IAPs \\
PARK14/22q13.1 & autosomal recessive & PLA2G6 & Phospholipase A2 group VI \\
PARK15/22q12-q13 & autosomal recessive & FBXO7 & F-box protein 7 \\
\hline
\end{tabular}

derivative nitrogen dioxide $\left(\mathrm{NO}_{2}\right)$, is a major signature of human PD and other synuclinopathies and might be critical to the aggregation process $[54,55]$.

\section{UCHL1 and Parkin}

UCHL1 is a very abundant protein $(\sim 1-2 \%$ total soluble protein in brain) that functions in the formation and recycling of ubiquitin monomers for the ubiquitinproteasome pathway [56]. This pathway is important for intracellular protein turnover and degradation and functions generally in quality control of proteins in cells to eliminate misfolded, mutated, and damaged proteins [57]. Ubiquitin is an abundant small $(\sim 8.5 \mathrm{kDa})$ protein that is attached covalently to lysine aliphatic chains in proteins to mark them for degradation carried out by the $26 \mathrm{~S}$ proteasome. UCHL1 hydrolyzes the C-terminus of fusion proteins containing polyubiquitin molecules and ribosomal protein, thus generating ubiquitin monomers. In vitro, PD-linked mutant UCHL1 has reduced enzyme activity [58], and inhibition of UCHL1 is associated with production of $\alpha$-Syn aggregates [59], indicating that $\alpha$-Syn is degraded by the proteasome.

The ubiquitination of proteins is catalyzed by the activities of three enzymes called ubiquitin-activating enzyme (E1), ubiquitin-conjugating enzyme (E2), and ubiquitin ligase (E3) [57]. PARK2, encoding Parkin, a ubiquitin E3 ligase, causes juvenile-onset recessive PD (before 40 years of age) [33] with relatively confined neuronal loss in the SNc and locus coeruleus, but with an absence of LBs. Several substrates of Parkin have been identified, including $\alpha$-Syn, synphilin-1, and other synaptic proteins [60]. Mutations in the parkin gene result in a loss-of-function of E3, thus possibly causing some substrates of Parkin to accumulate and aggregate within cells. One parkin mutation found in a Turkish patient $(\mathrm{Gln}-311 \rightarrow \mathrm{X})$, replacing a glutamine residue at position 311 with a stop codon) causes a C-terminal truncation of 155 amino acids of Parkin [61].

\section{PINK1}

The PARK6 locus contains the PINK1 gene [32,34]. $P A R K 6$ kindred have juvenile-onset $P D$ and truncation mutations or missense mutations in the PINK1 gene resulting in truncation or single amino acid substitutions in the PINK1 protein (His-271 $\rightarrow$ Gln; Gly-309 $\rightarrow$ Ala; Leu-347 $\rightarrow$ Pro; Glu-417 $\rightarrow$ Gly) as well as mutations that are nonsense $(\mathrm{Arg}-246 \rightarrow \mathrm{X}$, where $\mathrm{X}$ is any other amino acid; Trp-437 $\rightarrow \mathrm{X}$ ) or compound nonsense $($ Gln-309 $\rightarrow$ X/Arg-492 $\rightarrow X$ ).

Clues about the intracellular localization and normal functions of PINK1 are emerging. It is a 581 amino acid protein $(\sim 63 \mathrm{kDa})$ and contains a domain highly homologous to the serine/threonine protein kinases of the calcium/calmodulin family and a mitochondrial targeting motif [34]. Thus, PINK1 is a mitochondrial kinase. It is processed at the N-terminus in a manner consistent with mitochondrial import, but the mature protein is also present in the cytosol [62]. Both human wild-type and mutant PINK1 localize to mitochondria [63]. In- 
terestingly, most of the reported mutations are in the putative kinase domain. PINK1 is expressed in many adult human tissues [64]. In adult rodents PINK1 is expressed throughout the brain [65]. It is unclear how PINK1 mutations cause the selective death of SNc neurons in human PD (Fig. 2). PINK1 appears to function in mitochondrial trafficking by forming a multiprotein complex with the GTPase Miro and the adaptor protein Milton [66]. Speculation has PINK1 protecting human dopaminergic neuroblastoma cells ( $\mathrm{SH}-$ SY5Y) against mitochondrial malfunction under conditions of cell stress [67]. In rat neuroblastoma cells, mutant PINK1 can induce abnormalities in mitochondrial $\mathrm{Ca}^{2+}$ influx and aggravate the cytopathology caused by mutant $\alpha$-Syn in a mechanism that involves the mPTP (Fig. 1) [68].

\section{$D J-1$}

The PARK7 locus contains the DJ-1 gene [31]. PARK7 kindred can have homozygous deletion of a large region within the $D J-1$ gene causing complete loss of DJ-1 expression, or homozygous missense mutations in the $D J-1$ gene, resulting in single amino acid substitutions in the DJ-1 molecule (Met-26 $\rightarrow$ Ile; Glu$64 \rightarrow$ Asp; Leu-166 $\rightarrow$ Pro) [31].

DJ-1 is a small (189-amino acid, $\sim 20-25 \mathrm{kDa}$ ) protein with multiple apparent functions involving cellular transformation, male fertility, control of proteinRNA interaction, and oxidative stress response [31]. The protein exists in vivo as a dimer [69]. DJ-1 is expressed throughout the mouse nervous system [70], and it might act as a neuroprotective intracellular redox sensor that can localize to the cytoplasmic side of mitochondria [71]. The localization of DJ-1 to mitochondria is associated with protective actions against some mitochondrial poisons [71]. Some DJ-1 mutant proteins have abnormalities in dimer formation ability and decreased stability [72,73]. It remains to be identified how mutated DJ-1 proteins cause the selective death of SNc neurons in human PD (Fig. 2).

\section{LRRK2}

The PARK8 locus contains the LRRK2 gene [35, 36]. Mutations in this gene are to date the most common in both familial and "sporadic" PD. The LRRK2 protein is a large multidomain protein (2527 amino acids, $286 \mathrm{kDa}$ ) - also called dardarin (derived from the Basque word dardara, meaning tremor) - that is expressed throughout the body [35,36]. Currently, it is not evident how LRRK2 gene mutations relate to the selective death of neurons that causes human PD. LRRK2 contains leucine-rich repeat domains, a Ras/small GTPase domain, a non-receptor tyrosine kinase-like domain, and a WD40 domain ( $~ 40$ amino acid motifs often terminating in a Trp-Asp dipeptide), consistent with the architecture of multifunctional Ras/GTPases of the Ras of complex (ROC) family [35,36]. The presence of leucine-rich and WD40 domains suggests that LRRK2 is capable of multiple protein-protein interactions. The GTPase activity indicates that LRRK2 functions as a molecular switch, possibly involved in cytoskeleton organization and vesicle trafficking. The kinase domain possibly belongs to the mitogen-activated protein kinase kinase kinase (MAPKKK or MEKK) family of kinases. Studies of rodent brain show little or no expression of LRRK2 in SNc neurons [74,75]; however, expression of LRRK2 is high in dopamine-innervated brain regions [74]. Recent work shows that LRRK2 can influence mitochondrial- and death receptor-mediated cell death in cultured cells [76,77]. These findings might be hints that the target of SNc neurons (i.e., the striatum) and SNc neuron target-deprivation are important to the understanding of pathogenic mechanisms of PD (Fig. 2).

\section{PD $\alpha$-SYN TRANSGENIC MICE DEVELOP NEURONAL MITOCHONDRIAL DEGENERATION AND CELL DEATH}

Information gleaned from molecular genetic studies on human genes linked to familial PD drives experimental work on the generation of animal and cell models of PD. Parkin null mice appear to have a normal lifespan, do not develop any major neurological abnormalities, and have no loss of midbrain dopaminergic neurons and no formation of inclusions [78,79]. However, these mice exhibit some evidence of dopaminergic presynaptic dysfunction in striatum and possible deficits in behavioral tests indicative of nigrostriatal dysfunction [78], although this finding has not been confirmed in another mouse line [79]. Parkin ${ }^{-/-}$mice have decreases in proteins involved in mitochondrial oxidative phosphorylation and oxidative stress in ventral midbrain and exhibit reduced mitochondrial respiration in striatum, but they have no mitochondrial ultrastructural abnormalities [80]. Mice with null mutations in $D J-1$ also have a normal lifespan and do not develop an overt phenotype or loss of dopaminergic neurons, but behavioral tests reveal age-dependent motor deficits 
and neurochemical assessments show altered striatal dopamine content [81]. DJ-1 null mice also show altered D2 dopamine receptor-mediated function [82]. In contrast, transgenic (Tg) mice expressing the Parkin Q311X truncation mutation develop a progressive hypokinetic disorder, degeneration of SNc neurons, and loss of striatal dopamine [83]. Thus, Parkin could be important for maintenance of mitochondrial function or mitochondrial turnover through autophagy and synaptic integrity distally within the SNc neuron target region.

Several $\mathrm{Tg}$ mouse lines have been made using a variety of different promoters to drive expression of human full-length wild-type or mutant $\alpha$-Syn [53,84-89]. Of these mouse lines, Tg mice expressing human A53T mutant $\alpha$-Syn have a shortened lifespan and develop a severe movement disorder and synucleinopathy [53, $86,89]$. It is noteworthy that there have been no reports of robust dopamine SNc neuron degeneration in fulllength $\alpha$-Syn Tg mice or in any other Tg or null mouse models of PD-linked genes. However, Tg mice expressing a truncation mutant of human $\alpha$-Syn have an abnormal development-related loss of SNc neurons [90]. Cell death mechanisms or thresholds for cell death activation in human and mouse brain dopamine neurons might differ.

Despite the absence of prominent changes in the SNc, Tg $\alpha$-Syn mice do develop robust cell death and neuronal loss in other regions of brain and in spinal cord [91]. These Tg mice express high levels of human wild-type or mutant (A53T and A30P) $\alpha$-Syn under the control of the mouse prion protein promoter [86]. Mice expressing A53T $\alpha$-Syn (lines G2-3 and H5), but not mice expressing wild-type (line I2-2) or A30P (line O2) $\alpha$-Syn, develop adult-onset progressive motor deficits, including reduced spontaneous activity with bradykinesia, mild ataxia and dystonia, at $\sim 10-15$ months of age followed by rapidly progressive paralysis and death [86]. A53T mice develop intraneuronal inclusions, mitochondrial degeneration, and cell death in neocortex, brainstem, and spinal cord [91]. Brainstem neurons and spinal motor neurons display a prominent chromatolysis reaction and axonal spheroids [91], typical of that seen after axonal injury [92]. A53T mice form LB-like inclusions in neocortical and spinal motor neurons and have progressive, profound loss $(\sim 75 \%)$ of motor neurons that causes their paralysis [91]; motor neuron loss in A53T mice has been shown by another group [45].

Mitochondrial pathology in A53T mice involving mitochondrial DNA damage is seen frequently in the absence of nuclear DNA damage in large brainstem neurons and spinal motor neurons [91]. Subsets of mitochondria in brainstem and spinal cord cells in A53T mice appear dysmorphic, becoming shrunken, swollen, or vacuolated [91]. Human $\alpha-$ Syn is found bound to some mitochondria in degenerating neurons in A53T mice [91]. Some abnormal intracellular inclusions in these cells are degenerating mitochondria. A mitochondrial defect in A53T mice is further indicated by biochemical evidence revealing loss of complex IV activity [91].

The mechanisms for this mitochondrial DNA damage are possibly related to oxidative stress. The presence of oxidative stress in mutant $\alpha$-Syn Tg mice is shown by evidence that mitochondrial associated metabolic proteins are oxidized in A30P mice [93]. $\alpha$-Syn can generate $\mathrm{H}_{2} \mathrm{O}_{2}$ [94] and $\mathrm{OH}$ [95] in vitro upon incubation with $\mathrm{Fe}(\mathrm{II})$. We found evidence for $\mathrm{ONOO}^{-}$-mediated oxidative/nitrative stress in A53T mouse motor neurons as indicated by the presence of nitrated human synuclein [91]. Nitrated synuclein formed inclusions in motor neurons consistent with in vitro data showing that $\mathrm{ONOO}^{-}$promotes the formation of stable $\alpha$-Syn oligomers [96,97]. Our data showing mitochondrial DNA damage is in line with the presence of $\mathrm{ONOO}^{-}$or its derivatives near mitochondria, because $\mathrm{ONOO}^{-}$or products of $\mathrm{ONOO}^{-}$are directly genotoxic by causing single- and double-strand breaks in DNA [8]. Moreover, the loss of complex IV enzyme activity without a change in protein level [91] might be explained by inactivation of this mitochondrial enzyme by nitration. Overall, $\mathrm{ONOO}^{-}$mediated damage in mitochondria may be a key pathological mechanism leading to motor neuron degeneration in A53T mice.

The reasons for the vulnerability of mouse motor neurons to human A53T mutant $\alpha$-Syn are not clear. These mice express high levels of mRNA and protein for human $\alpha$-Syn in the forebrain, diencephalon, and midbrain [86], but these regions are much less vulnerable than spinal cord. A53T $\alpha$-Syn causes axonopathy $[53,89]$, thus motor neuron vulnerability could be related to their long myelinated axons and interactions with oligodendrocytes and Schwann cells for myelin support. Motor neuron vulnerability could also be related to their unusual expression of inducible NOS (iNOS) in mitochondria $[98,99]$. Moreover, distal axonopathy and muscle disease may have roles in the pathogenesis in A53T mice [91]. Prominent skeletal muscle denervation occurs in $\alpha$-Syn Tg mice [89,91]. This work is intriguing because the original goal was to develop a Tg mouse model of PD, but our result is a profound 
mouse model of ALS. Thus, the mutant $\alpha$-Syn A53T Tg mouse is a new model to study mechanisms of motor neuron degeneration and could provide insight into the selective vulnerability of motor neurons in age-related disorders and the possible roles of $\alpha$-Syn in synaptic maintenance and diseases of long-axon neurons [91].

\section{AMYOTROPHIC LATERAL SCLEROSIS}

ALS is a progressive and severely disabling neurological disease in humans characterized by initial muscle weakness, and then muscle atrophy, spasticity, and eventual paralysis and death typically 3 to 5 years after symptoms begin [100]. The cause of the spasticity, paralysis, and death is progressive degeneration and elimination of upper motor neurons in cerebral cortex and lower motor neurons in brainstem and spinal cord (Fig. 3) [100,101]. Degeneration and loss of spinal and neocortical interneurons has also been found in human ALS [102,103]. More than 5000 people in the USA are diagnosed with ALS each year (ALS Association, http://www.alsa.org), and, in parts of the United Kingdom, three people die every day from some form of motor neuron disease (http://www.mndassociation.org). Other than life support management, no effective treatments exist for ALS [104].

It is still not understood why specific neuronal populations are selectively vulnerable in ALS, such as certain somatic motor neurons and interneurons [100103]. The molecular pathogenesis of ALS is understood poorly, contributing to the lack of appropriate target identification and effective mechanism-based therapies to treat even the symptoms of this disease. At least two forms of ALS exist: idiopathic (sporadic) and heritable (familial). The majority of people with ALS has no known genetic contributions and are designated sporadic. Aging is a strong risk factor for ALS because the average age of onset is 55 (ALS Association, http://www.alsa.org). Familial forms of ALS have autosomal dominant or autosomal recessive inheritance patterns and make up $\sim 10 \%$ or less of all ALS cases. ALS-linked mutations occur in the genes (Table 2) encoding SOD1 (ALS1), Alsin (ALS2), senataxin (ALS4), fused in sarcoma (FUS, ALS6), vesicle associated membrane protein (VAMP/synaptobrevin)-associated protein B (VAPB, ALS8), p150 dynactin (DCTN1), and TAR-DNA binding protein (TADBP or TDP43) [105108]. Most recently, variations in the phosphoinositide phosphatase FIG4 gene cause ALS11 [109]. Several other genes are believed to be susceptibility factors for ALS (Table 2).

\section{MITOCHONDRIAL DYSFUNCTION IN HUMAN ALS}

Human ALS is associated with mitochondrial abnormalities. Structural abnormalities in mitochondria are seen by electron microscopy in skeletal muscle, liver, spinal motor neurons, and motor cortex of ALS patients [110,111]. A mutation in cytochrome $c$ oxidase subunit I was found in a patient with a motor neurons disease phenotype [112]. Another patient with motor neuron disease had a mutation in a mitochondrial tRNA gene [113]. One type of mitochondrial DNA (mtDNA) mutation, called the common mtDNA deletion (mtDNA4977), is found non-uniformly within different human brain areas; the highest levels are detected in the striatum and SN [114,115]. However, no significant accumulation of the $5 \mathrm{~kb}$ common deletion in mtDNA has been found by single-cell analysis of motor neurons from sporadic ALS cases compared to controls [116]. This finding contrasts with the high levels of mtDNA deletions that accumulate in SNc neurons in human PD [117,118]. Overall, there is a lack of strong direct evidence for mitochondrial abnormalities participating in disease-causing mechanisms of human ALS, despite many associational/correlative data from human and animal/cell models.

Intracellular $\mathrm{Ca}^{2+}$ abnormalities and excitotoxicity are suspected links to mitochondrial dysfunction and oxidative stress in ALS. Mitochondria regulate cytoplasmic $\mathrm{Ca}^{2+}$ levels $[1,2,119]$. Skeletal muscle biopsies of people with sporadic ALS show ultrastructural changes indicative of elevated $\mathrm{Ca}^{2+}$ in motor neuron terminals, with some mitochondria showing an augmented $\mathrm{Ca}^{2+}$ signal [120]. Utilizing specific transport systems, mitochondria can pump $\mathrm{Ca}^{2+}$ from the cytosol into the matrix by the $\mathrm{Ca}^{2+}$ uniporter and eject $\mathrm{Ca}^{2+}$ from the matrix via the $\mathrm{Na}^{+} / \mathrm{Ca}^{2+}$ exchanger [2] and more catastrophically through the MPTP [121]. Under conditions of elevated cytoplasmic $\mathrm{Ca}^{2+}$, whenever the local free $\mathrm{Ca}^{2+}$ concentration rises above a set-point of $\sim 0.5 \mu \mathrm{M}$, mitochondria avidly accumulate $\mathrm{Ca}^{2+}$ to a fixed capacity [2]. The electrical gradient across the IMM, the $\Delta \Psi_{m}$, established by electron transport chain activity (Fig. 1), provides the driving force for the accumulation of $\mathrm{Ca}^{2+}$ into the mitochondrial matrix [119]. Cytosolic $\mathrm{Ca}^{2+}$ concentrations above set-point levels are believed to be achieved during tetanic stimulation and by activation of glutamate receptors on the plasma membrane [2]. In pathological settings of excitotoxicity, resulting from excessive overstimulation of glutamate receptors $[122,123], \mathrm{Ca}^{2+}$ overload in neu- 


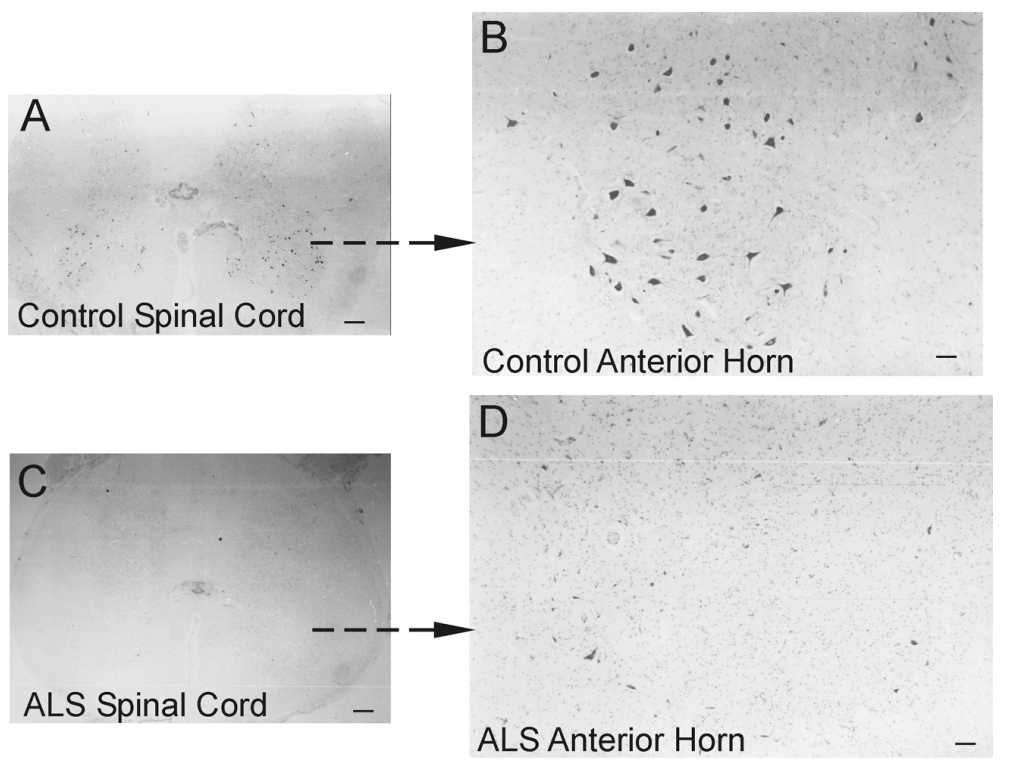

Fig. 3. Motor neurons in spinal cord degenerate in people with ALS. A, B) In normal control individuals, the anterior horns of the spinal cord contain many large, multipolar motor neurons (dark cells). C, D) In ALS cases, the anterior horn is depleted of large neurons (dark cells) and remaining neurons are atrophic. These attritional chromatolytic motor neurons display a dark condensed nucleus as seen microscopically (see Fig. 4). Scale bars: A, $500 \mu \mathrm{m}$ (same for C); B, $76 \mu \mathrm{m}$ (same for D).

rons is significant and causes cell death [124]. When mitochondria become overloaded with $\mathrm{Ca}^{2+}$, they undergo mitochondrial permeability transition resulting in osmotic swelling and rupture of the OMM (Fig. 1). Mitochondria within synapses appear to be more susceptible than non-synaptic mitochondria to $\mathrm{Ca}^{2+}$ overload [125].

Excitotoxicity has been implicated in the pathogenesis of ALS for a long time [126] and is another possible mechanism of motor neuron damage in ALS [124]. While many drugs targeting excitotoxicity as a mechanism have failed in human ALS clinical trials, the anti-excitotoxic drug riluzole has been approved by the Food and Drug Administration for ALS treatment [104]. Many sporadic ALS patients have reduced levels of synaptosomal high-affinity glutamate uptake [126] and astroglial glutamate transporter EAAT2 (excitatory amino acid transporter 2 or GLT1) in motor cortex and spinal cord [127]. Reductions in levels of activity of EAAT2 in spinal cord could increase the extracellular concentrations of glutamate at synapses on motor neurons. Motor neurons might be particularly sensitive to glutamate excitotoxicity because they have a low proportion of GluR2edited or under-edited AMPA subtype glutamate receptor on their surfaces, predisposing these cells to risk of excess $\mathrm{Ca}^{2+}$ entry and mitochondrial perturbations $[128,129]$. Cell culture studies show that ex- cess glutamate receptor activation in neurons can cause increased intracellular $\mathrm{Ca}^{2+}$, mitochondrial ROS production, bioenergetic failure, and mitochondrial trafficking abnormalities [130]. $\mathrm{Ca}^{2+}$-induced generation of ROS in brain mitochondria is mediated by mitochondrial permeability transition [131]. Motor neurons are particularly affected by inhibition of mitochondrial metabolism, which can cause elevated cytosolic $\mathrm{Ca}^{2+}$ levels and increased excitability [132].

Markers of oxidative stress and ROS damage are elevated in human ALS tissues [133]. In human sporadic and familial ALS, protein carbonyls are elevated in motor cortex [134]. Tyrosine nitration is elevated in human ALS nervous tissues [135-137]. Studies of respiratory chain enzyme activities are discrepant. Experiments have shown increases in complex I, II, and III activities (Fig. 1) in vulnerable and non-vulnerable brain regions in patients with familial ALS-mutant SOD1 [138], but experiments by others show decreased complex IV activity in spinal cord ventral horn [139] and skeletal muscle [140] of sporadic ALS cases. In sporadic ALS skeletal muscle, reductions in activity of respiratory chain complexes with subunits encoded by the mitochondrial genome are associated with reduced mtDNA content [140] and decreased NOS levels [141]. Alterations in skeletal muscle mitochondria are progressive [142] and could be intrinsic to skeletal muscle and not due merely to neurogenic atrophy, as is assumed commonly. 
Table 2

Mutant/Polymorphic Genes Linked to Familial ALS

\begin{tabular}{|c|c|c|c|}
\hline Locus & Inheritance & Gene & Protein name/ function \\
\hline ALS1/21q22 & $\begin{array}{l}\text { autosomal dominant (adult } \\
\text { onset) }\end{array}$ & SOD1 & $\mathrm{Cu} / \mathrm{Zn}$ superoxide dismutase/ dismutation of supeoxide \\
\hline ALS2/2q33.2 & $\begin{array}{l}\text { autosomal recessive (juve- } \\
\text { nile onset primary lateral } \\
\text { sclerosis) }\end{array}$ & Alsin & Alsin/guanine exchange factor for RAB5A and Rac1 \\
\hline ALS4/9q34 & $\begin{array}{l}\text { autosomal dominant (adult } \\
\text { onset) }\end{array}$ & SETX & Senataxin/helicase, RNA processing \\
\hline ALS6/16q12 & $\begin{array}{l}\text { autosomal recessive (adult } \\
\text { onset) }\end{array}$ & FUS & $\begin{array}{l}\text { Fused in sarcoma, component of heterogeneous nuclear } \\
\text { ribonuclear protein complex; RNA/DNA binding protein }\end{array}$ \\
\hline ALS8/20q13.33 & autosomal dominant & VAPB & VAMP-associated protein B/part of SNARE complex \\
\hline $2 q 13$ & $\begin{array}{l}\text { autosomal dominant (adult } \\
\text { onset, atypical ALS) }\end{array}$ & DCTN1 & 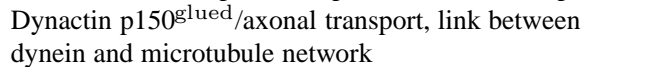 \\
\hline ALS10/1p36.22 & autosomal dominant & TARDBP & $\begin{array}{l}\text { TAR DNA binding protein, DNA and RNA binding pro- } \\
\text { tein, regulates RNA splicing }\end{array}$ \\
\hline ALS11/6q21 & autosomal recessive & FIG4 & $\begin{array}{l}\text { FIG4 homolog, SAC1 lipid phosphatase domain contain- } \\
\text { ing; regulates phosphotidylinositol turnover }\end{array}$ \\
\hline $14 q 11.1-q 11.2$ & susceptibility factor & ANG & Angiogenin; angiogenesis; tRNA RNase \\
\hline $22 \mathrm{q} 12.2$ & susceptibility factor & NEFH & Neurofilament, heavy polypeptide; neurofilament subunit \\
\hline $12 q 12-q 13$ & susceptibility factor & PRPH & Peripherin; intermediate filament formation \\
\hline $5 q 13$ & susceptibility factor & SMN1/SMN2 & Survival motor neuron; RNA processing \\
\hline $7 q 36.6$ & susceptibility factor? & DPP6 & $\begin{array}{l}\text { Dipeptidyl-peptidase } 6 \text {; S9B serine protease, binds } \\
\text { voltage-gated potassium channels }\end{array}$ \\
\hline
\end{tabular}

\section{HUMAN ALS AND \\ MITOCHONDRIAL-ORCHESTRATED PCD INVOLVING P53}

PCD appears to contribute to the selective degeneration of motor neurons in human ALS, albeit seemingly as a non-classical form differing from apoptosis (Fig. 4) [143,144]. Motor neurons appear to pass through sequential stages of chromatolysis (suggestive of initial axonal injury [92]), somatodendritic attrition without extensive cytoplasmic vacuolation, and then nuclear DNA fragmentation, nuclear condensation, and cell death (Fig. 4) [143]. Motor neurons in people that have died from sporadic ALS and familial ALS show the same type of degeneration [143]. This cell death in human motor neurons is defined by genomic DNA fragmentation (determined by DNA agarose gel electrophoresis and in situ DNA nick-end labeling) and cell loss and is associated with accumulation of perikaryal mitochondria, cytochrome $c$, and cleaved caspase-3 [143-145]. p53 protein increases in vulnerable CNS regions in people with ALS, and it accumulates specifically in the nucleus of lower and upper motor neurons [146]. This p53 is active functionally because it is phosphorylated at serine ${ }^{392}$ and has increased DNA binding activity $[146,147]$. However, the morphology of this cell death is distinct from classical apoptosis, despite the nuclear condensation [12,143,147]. Nevertheless, Bax and Bak1 protein levels are increased in mitochondria-enriched fractions of selectively vulnera- ble motor regions (spinal cord anterior horn and motor cortex gray matter), but not in regions unaffected by the disease (somatosensory cortex gray matter) [143]. In marked contrast, Bcl-2 protein is depleted severely in mitochondria-enriched fractions of affected regions and is sequestered in the cytosol [143]. Although these western blot results lacked direct specificity for motor neuron events [143], subsequent immunohistochemistry [144] and laser capture microdissection of motor neurons, combined with mass spectroscopy-protein profiling, have confirmed the presence of intact active caspase-3 in human ALS motor neurons [145].

Our studies [143,145-147] support the concept of an aberrant re-emergence of a mitochondrial-directed PCD mechanism, involving p53 activation and redistributions of mitochondrial cell death proteins, participating in the pathogenesis of motor neuron degeneration in human ALS (Figs. 1, 4). The morphological and biochemical changes seen in human ALS are modeled robustly and faithfully at structural and molecular levels in axotomy models of motor neuron degeneration in adult rodents $[148,149]$ but not in the current commonly used human mutant SOD1 Tg mouse models [98,144]. The role of mitochondria in human ALS pathogenesis is further supported by recent work that suggests a lithium treatment may be beneficial in ALS through mitochondrial autophagy [150] (see Appendum). 


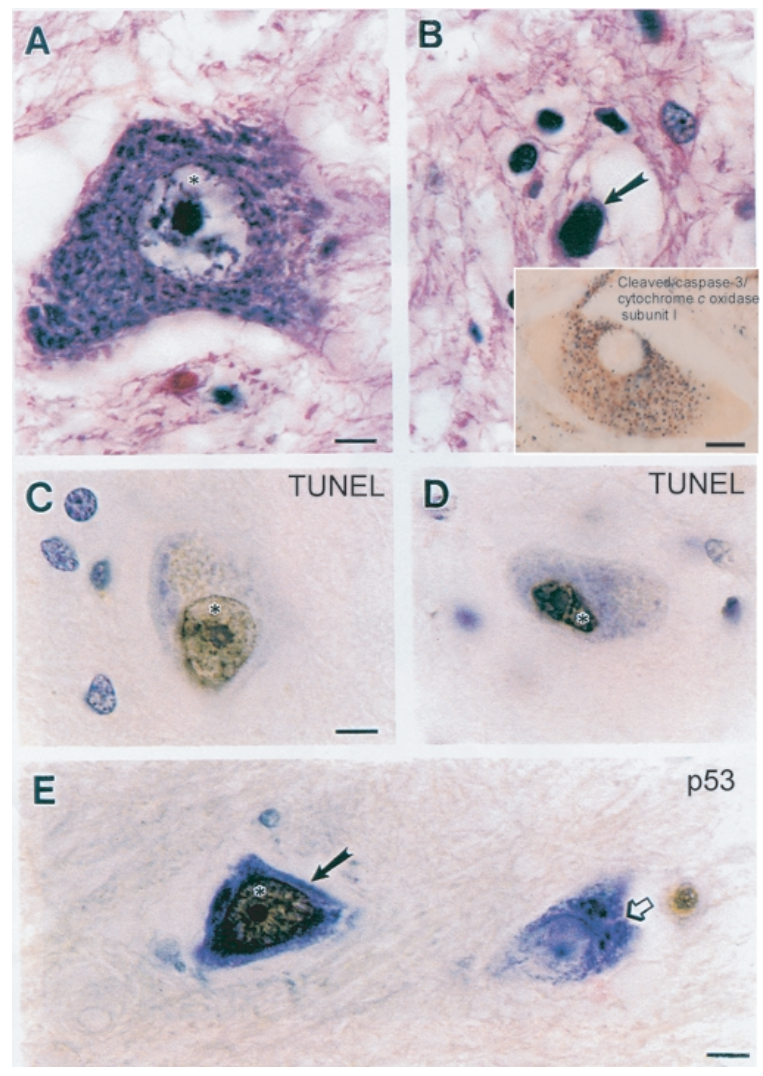

Fig. 4. Features of motor neuron degeneration in human ALS. A, B) H\&E staining shows that the degeneration of motor neurons in human familial ALS is characterized by shrinkage and progressive condensation of the cytoplasm and nucleus. The motor neuron in A appears normal. It has a large, multipolar cell body and a large nucleus (asterisk) containing reticular network of chromatin and a large nucleolus. Scale bar $=$ $7 \mu \mathrm{m}$ (same for B). The motor neuron is B has undergone severe somatodentritic attrition and is at near endstage degeneration (arrow). The cell has shrunken to about $10 \%$ of normal size and has become highly condensed. The cell in B is identified as a residual motor neuron based the large nucleolus and residual large Nissl bodies. Inset in B) Degenerating motor neurons in human ALS are immunopositive for cleaved caspase-3 (black-dark green labeling) in the somatodendritic attrition stage and accumulate around the nucleus (pale circle) discrete mitochondria (brown-orange labeling, detected with antibody to cytochrome $c$ oxidase subunit I) exhibiting little light microscopic evidence for swelling. C, D) Cell death assays (e.g., TUNEL) identify subsets of motor neurons in the process of DNA fragmentation. Nuclear DNA fragmentation (asterisk, brown labeling) occurs in motor neurons in people with ALS as the nucleus condenses (asterisks) and the cell shrinks. Motor neurons in the somatodendritic attrition stage accumulate DNA double strand breaks. Scale bar (C) $=7 \mu \mathrm{m}$ (same for D). E) In individuals with ALS, p53 accumulates in the nucleus (asterisk, brown labeling) of motor neurons (arrow). The nearby neuron (open arrow) has an unlabeled nucleus for comparison. Scale bar $=10 \mu \mathrm{m}$.

\section{MITOCHONDRIAL PATHOBIOLOGY IN CELL AND MOUSE MODELS OF ALS}

A common genetic mutation in human $S O D 1$ that is linked to familial ALS (Table 2) is the substitution of glycine by alanine at position 93 (G93A) [151]. SOD1 is a metalloenzyme of 153 amino acids $(\sim 16 \mathrm{kDa})$ that binds one copper ion and one zinc ion per subunit $[4,152]$. This enzyme, functioning as a $\sim 32 \mathrm{kDa}$ non-covalently linked homodimer, is responsible for the detoxification and maintenance of intracellular $\mathrm{O}_{2}^{-}$ concentration in the low femtomolar range by catalyzing its dismutation (Fig. 1) [4,152]. SOD1 is ubiquitous (intracellular SOD concentrations are typically $\sim 10$ 40 micromolar) in most tissues, possible with highest levels in neurons [153].

Cell culture experiments reveal mitochondrial dysfunction in the presence of human mutant SOD1 (mSOD1) [154]. Expression of several mSOD1 variants increases mitochondrial $\mathrm{O}_{2}^{-}$levels and causes toxicity in rat primary embryonic motor neurons [155], human neuroblastoma cells [156], and NSC-34 cells (a hybrid cell line with some motor neuron-like characteristics, produced by fusion of motor neuron-enriched embryonic mouse spinal cord cells with mouse neuroblastoma cells) [157]. These responses can be attenuat- 
ed by over-expression of MnSOD [156]. ALS-mSOD1 variants, compared to human wild-type SOD1, associate more with mitochondria in NSC-34 cells, and appear to form cross-linked oligomers that shift the mitochondrial GSH/GSSH ratio toward oxidation [154].

Gurney and colleagues were the first to develop $\mathrm{Tg}$ mice that express human mSOD1 $[158,159]$. Now, these mice are used widely as an animal model of ALS [144,151]. In these mice, human mSOD1 is expressed ubiquitously driven by its endogenous promoter in a tissue/cell non-selective pattern against a background of normal mouse SOD1 [158]. Effects of this human mutant gene in mice are profound. Hemizygous Tg mice expressing high copy number of the G93A variant of human SOD1 become completely paralyzed and die at $\sim 16-18$ weeks of age [158]. G93A-mSOD1 mice with reduced transgene copy number have a much slower disease progression and die at $\sim 8-9$ months of age $[158,160]$.

Spinal motor neurons and interneurons in mice expressing G93 $\mathrm{A}^{\text {high }}$-mSOD1 undergo prominent degeneration; about $80 \%$ of lumbar motor neurons are eliminated by end-stage disease $[98,161]$. Subsets of spinal interneurons degenerate before motor neurons in G93 $\mathrm{A}^{\text {high }}$-mSOD1 [98] and some are the glycinergic Renshaw cells [161]. Unlike the degeneration of motor neurons in human ALS [143], motor neurons in these mice do not degenerate with a morphology resembling any form of apoptosis or apoptosis-necrosis hybrids $[12,98,147,160]$. The motor neurons degeneration seen in G93 $\mathrm{A}^{\text {high }}$-mSOD1 mice more closely resembles a prolonged necrotic-like cell death process [98, 160] involving early-occurring mitochondrial damage, cellular swelling, and dissolution [98,161-166]. Biochemically, the death of motor neurons in G93 $\mathrm{A}^{\text {high }}$ mSOD1 is characterized by somal and mitochondrial swelling and formation of DNA single-strand breaks prior to double-strand breaks occurring in nuclear DNA and mtDNA [98]. The motor neuron death in G93A high mSOD1 mice is independent of activation of caspases1 and -3 , and also appears to be independent of capsase8 and AIF activation within motor neurons [98]. Indeed, caspase-dependent and p53-mediated apoptosis mechanisms might be blocked actively in G93 $\mathrm{A}^{\text {high }}$ mSOD1 mouse motor neurons, possibly by upregulation of inhibitors of apoptosis and changes in the nuclear import of proteins [98]. More work is needed on cell death and its mechanisms in G93A ${ }^{\text {low }}$-mSOD1 mice, because these mice could be more relevant physiologically and clinically to the human disease compared to G93A $\mathrm{A}^{\text {high }}$-mSOD1 mouse.
Mitochondrial pathology has been implicated in the mechanisms of motor neuron degeneration in $\mathrm{Tg}$ mSOD1 mouse models [162-166], but until recently, most evidence is circumstantial. In different mSOD1 mouse models of ALS, mitochondria in spinal cord neurons exhibit structural pathology $[98,162-166]$ and some of the mitochondrial degeneration occurs very early in the course of the disease [98,162]. Mitochondrial microvacuolar damage in motor neurons emerges, as seen by electron microscopy, by 4 weeks of age in G93A ${ }^{\text {high }}$ mice [98]. It has been argued that mitochondrial damage in G93 $\mathrm{A}^{\text {high }}$-mSOD1 mice is related to supra-normal levels of SOD1 and might not be related causally to the disease process because Tg mice expressing high levels of human wild-type SOD1 show some mitochondrial pathology [165], but mitochondrial abnormalities have also been found histologically in G93 $\mathrm{A}^{\text {low }}$-mSOD1 mice [166]. Thus, mitochondria could be primary sites of human SOD1 toxicity in Tg mice irrespective of transgene copy number and expression level of human SOD1, but direct, unequivocal causal relationships have been lacking.

Human mSOD1 proteins appear to acquire a toxic property or function, rather than having diminished $\mathrm{O}_{2}^{-}$scavenging activity $[106,167,168]$, and wildtype SOD1 can gain toxic properties through loss of $\mathrm{Zn} \mathrm{[155]} \mathrm{and} \mathrm{oxidative} \mathrm{modification} \mathrm{[169,170].} \mathrm{A}$ gain in aberrant oxidative chemistry appears to contribute to the mechanisms of mitochondriopathy in G93A ${ }^{\text {high }}$ mice [7,171]. G93A-mSOD1 has enhanced free radical-generating capacity compared to wildtype enzyme [168] and can catalyze protein oxidation by hydroxyl-like intermediates and carbonate radical [172]. G93A $\mathrm{A}^{\text {high }}$ mice have increased protein carbonyl formation in total spinal cord tissue extracts at pre-symptomatic disease [173]. Protein carbonyl formation in mitochondrial membrane-enriched fractions of spinal cord is a robust signature of incipient disease [150]. A mass spectroscopy study of G93A high mice identified proteins in total spinal cord tissue extracts with greater than baseline carbonyl modification, including SOD1, translationally controlled tumor protein, and UCHL1 [174]. Nitrated and aggregated cytochrome $c$ oxidase subunit-I and $\alpha$-Syn accumulate in G93A ${ }^{\text {high }}$ mouse spinal cord [98]. Nitrated MnSOD also accumulates in G93 $\mathrm{A}^{\text {high }}$ mouse spinal cord [98]. Toxic properties of mSOD1 might also be mediated through protein binding or aggregation. Endogenous mouse SOD1 [175] and human wild-type SOD1 and mSOD1 [176] associate with mitochondria. Human SOD1 mutants associate with spinal cord mitochondria 
in mSOD1 mice and can bind Bcl-2 [176,177], thus potentially being decoys or dominant negative regulators of cell survival molecules (Fig. 1), but it is not known if this process is occurring specifically in motor neurons. Binding of mSOD1 (and perhaps its low-mobility species) to mitochondria has been reported to be spinal cord selective and age-dependent [178], but this work also lacks cellular resolution. A recent biochemical in vitro study has shown that endogenous SOD1 in the mitochondrial intermembrane space controls cytochrome $c$-catalyzed peroxidation and that G93A-mSOD1 mediates greater ROS production in the intermembrane space compared to wild-type SOD1 [179]. Human SOD1 mutants can also shift mitochondrial redox potential when expressed in cultured cells [154]. Nevertheless, the direct links between the physicochemical changes in wild-type and mutant SOD1 and the mitochondrial functional and structural changes associated with ALS and motor neuron degeneration remain uncertain.

EM studies of motor neurons in G93 $\mathrm{A}^{\text {high }}$ mice have shown that the outer mitochondrial membrane (OMM) remains relatively intact to permit formation of megamitochondria [160,161]. Moreover, early in the disease of these mice, mitochondria in dendrites in spinal cord ventral horn undergo extensive cristae and matrix remodeling, while few mitochondria in motor neuron cell bodies show major structural changes [160]. Thus, the disease might start distally in the motor neuron processes [98,161]. Another interpretation of ultrastructural findings is that the mSOD1 causes mitochondrial degeneration by inducing OMM extension and leakage and intermembrane space expansion [180]. Mechanisms for this damage could be related to mSOD1 gaining access to the mitochondrial intermembrane space $[175,180]$. This mitochondrial conformation seen by EM might favor the formation of the MPTP (Fig. 1); indeed, we found evidence for increased contact sites between the OMM and IMM in dendritic mitochondria in G93A high mice [160]. Another feature of motor neurons in young G93 $\mathrm{A}^{\text {high }}$ mice, before symptoms emerge, is apparent fission of ultrastructurally normal mitochondria in cell bodies and fragmentation of abnormal mitochondria [160]. It is not clear if the cristae and matrix remodeling and the apparent fragmentation and fission mitochondria are related or independent events and if these abnormalities interfere with mitochondrial trafficking; nevertheless, morphological observations enforce the idea that mitochondria could be important to the pathobiology of mSOD1 toxicity to motor neurons in $\mathrm{G} 93 \mathrm{~A}^{\text {high }}$ mice.
We have hypothesized that mitochondrial trafficking perturbations occur in motor neurons of mSOD1 [98]. Some data support the novel idea that mitochondria might act as messengers from distal regions of motor neurons in mSOD1 mice. G93 $\mathrm{A}^{\text {high }}$-mSOD1 mouse motor neurons accumulate mitochondria from the axon terminals and generate higher levels of $\mathrm{O}_{2}^{-}$, $\mathrm{NO}$, and $\mathrm{ONOO}^{-}$than motor neurons in $\mathrm{Tg}$ mice expressing human wild-type SOD1 [98]. This mitochondrial accumulation occurs at a time when motor neuron cell body volume is increasing, suggestive of ongoing abnormalities with ATP production or plasma membrane $\mathrm{Na}^{+}, \mathrm{K}^{+}$ATPase [98]. G93A-mSOD1 perturbs anterograde axonal transport of mitochondria in cultured primary embryonic motor neurons [181] making it possible that retrogradely transported mitochondria with toxic properties from the neuromuscular junction fail to be returned to distal processes [98]. Mitochondria with enhanced toxic potential from distal axons and terminals could therefore have a "Trojan horse" role in triggering degeneration of motor neurons in ALS via retrograde transport from diseased skeletal muscle.

Motor neurons in G93 $\mathrm{A}^{\text {high }}$-mSOD1 mice also accumulate higher levels of intracellular $\mathrm{Ca}^{2+}$ than motor neurons in human wild-type SOD1 Tg mice [98]. The intracellular $\mathrm{Ca}^{2+}$ signal in motor neurons is very compartmental and mitochondrial-like in its appearance [98,182]. Abnormal elevations intracellular $\mathrm{Ca}^{2+}$ in G93 $\mathrm{A}^{\text {high }}$-mSOD1 mouse motor neurons have been seen also by different $\mathrm{Ca}^{2+}$ detection methods [183, 184]. Recent work on a mouse neuromuscular junction preparation has shown that mitochondrial $\mathrm{Ca}^{2+}$ accumulation is accompanied by greater mitochondrial depolarization, specifically within motor neuron terminals of human mutant SOD1 Tg mice [185].

NO signaling mechanisms in mitochondria of ALS mice appear to be involved in the pathogenesis. Motor neurons seem to be unique regarding NO production because they express constitutively low levels of inducible NO synthase (iNOS) $[98,99,182]$. G93A $\mathrm{A}^{\text {high }}$-mSOD1 mouse motor neurons accumulate nicotinamide adenine dinucleotide phosphate diaphorase and iNOSlike immunoreactivity $[98,99]$. iNOS is also upregulated aberrantly in human sporadic ALS motor neurons [186]. iNOS gene knockout [98] and iNOS inhibition with $1400 \mathrm{~W}$ [99] extend significantly the lifespan of G93A $\mathrm{A}^{\text {high }}$-mSOD1 mice. Thus, mitochondrial oxidative stress, $\mathrm{Ca}^{2+}$ dysregulation, iNOS activation, protein nitration, and protein aggregation (not necessarily SOD1 though) are all likely intrinsic, cell automonous mechanisms in the process of motor neu- 
ron degeneration caused by mSOD1 in mice [99]. The mechanistic basis for the differences between human ALS and mSOD1 mice, regarding cell death phenotype $[14,144]$, is not yet clear, but could be related to the extreme non-physiological expression of toxic mSOD1 or to fundamental differences in cell death mechanisms in human and mouse neurons [144] or tissue inflammation that drive motor neurons in mSOD1 Tg mice to necrotic-like death according to the cell death matrix [187]. Another contributing factor for this difference between human and mouse motor neurons is that mitochondria are functionally diverse and have speciesspecific activities and molecular compositions, including the makeup of the mPTP (Fig. 1) [188]. These possibilities allow for skepticism regarding the suitability of existing Tg mSOD1 mouse lines to model human ALS (see Appendum).

\section{THE MPTP CONTRIBUTES TO THE DISEASE MECHANISMS OF ALS IN MICE}

Despite the implication of toxic effects of mSOD1 on mitochondria in mouse ALS, cause-effect relationships between abnormal functioning of mitochondria and initiation and progression of disease have been uncertain. These relationships need to be known because this knowledge could lead to new mechanism-based treatments for ALS. One specific target of investigation for mitochondria in disease causality is the MPTP.

The mPTP was first implicated in mouse ALS pathogenesis using pharmacological approaches. Cyclopsorine A treatment of G93A ${ }^{\text {high }}$ mice, delivered intracerebroventricularly or systemically to mice on a multiple drug resistance type $1 \mathrm{a} / \mathrm{b}$ background, improved outcome modestly [189-191]. These studies were confounded by the immunosuppressant actions of cyclopsorine A through calcineurin inhibition. Pharmacological studies using CyPD inhibitors devoid of effects on calcineurin need to be done on ALS mice. Another study showed that treatment with cholest-4-en-3one oxime (TRO19622), a drug that binds VDAC and the $18 \mathrm{kDa}$ translocator protein (TSPO, or peripheral benzodiazepine receptor), improved motor performance, delayed disease onset, and extended survival of G93 $\mathrm{A}^{\text {high }}$ mice [192]. However, another study using a different TSPO ligand (Ro-4864) did not show positive effects with G93A ${ }^{\text {high }}$ mice [193].

We identified CyPD and ANT as targets of nitration in ALS mice [160]. CyPD nitration is elevated in earlyto mid-symptomatic stages, but declines to baseline at end-stage disease [160]. ANT nitration is pertinent because it occurs in pre-symptomatic and symptomatic stages but not at end-stage disease or in Tg mice expressing human wild-type SOD1 [160]. The ANT is important in the context of age-related neurodegenerative disease because it undergoes carbonyl modification during aging as seen in housefly flight muscle [194] and rat brain [195]. In vitro cell-free and cell experiments have shown that $\mathrm{NO}$ and $\mathrm{ONOO}^{-}$can act directly on the ANT to induce mitochondrial permeabilization in a cyclosporine A-sensitive manner [196]. Oxidative stress enhances the binding of CyPD to ANT [197]. Some SOD1 mutants are unstable and lose copper [448], and interestingly, copper interactions with ANT and thiol modification of ANT can cause mPTP opening [198, 199]. Together these data and future work could reveal that oxidative and nitrative damage to proteins, some of which are core components of the MPTP, in G93A $\mathrm{A}^{\text {high }}$ mice is targeted rather than stochastic and could impinge on the functioning of the MPTP.

We examined the role of CyPD in the process of motor neuron disease in ALS mice through geneablation [160]. G93A $\mathrm{A}^{\text {high }}$-mSOD1 mice without CyPD show markedly delayed disease onset and lived significantly longer than Tg mice with CyPD. The effect of CyPD deletion was much more prominent in females than in males [160]. Remarkably, female mice showed positive effects with only haplo-deletion of CyPD. Ppif gene ablation in Tg mice with much lower levels of human mSOD1 expression and a slower disease progression (G93A ${ }^{\text {low }}$-mSOD1 mice) also show significantly delayed disease onset and lived significantly longer than Tg mice with CyPD [160]. Thus, some form of mPTP pathobiology is occurring regardless of whether transgene expression of G93A is high or low.

Nevertheless, most G93A-mSOD1 mice without CyPD eventually develop motor neuron disease and die. Other work on CypD null mice has shown that high concentrations of $\mathrm{Ca}^{2+}(2 \mathrm{mM})$ can still lead to $\mathrm{mPTP}$ activation without $\mathrm{CyPD}$ and that cell deaths caused by Bid, Bax, DNA damage and TNF- $\alpha$ still occur without CyPD [200]. The effects of CyPD deficiency on motor neuron cell mechanisms thus need detailed examination, but the cell death phenotype might switch or convert to another form with the attenuation of mitochondrial swelling. A switch in the cell death morphology and molecular mechanisms in motor neurons of mSOD1 mice without CyPD is an outcome consistent with the cell death matrix concept [187]. 


\section{SUMMARY AND OUTLOOK}

Mitochondria have diverse functions and properties and could be critically important for the development of PD and ALS. Structural and biochemical data from studies of human autopsy CNS as well as cell and animal models of these neurodegenerative disorders suggest that mitochondrial dysfunction is a trigger or propagator of neurodegeneration. Novel mechanisms for mitochondriopathy and neurodegeneration could involve the MPTP (Fig. 1). There is precedence for this logic in mouse models of Alzheimer's disease [201], multiple sclerosis [101], stroke [202], and ALS [160]. The mPTP actively participates in the mechanisms of motor neuron death in ALS mice in a gender-dependent pattern [160]. Thus, mPTP activation is a possible triggering event for motor neuron degeneration, and motor neuron selective vulnerability in ALS could be related to amount, composition, and trafficking of mitochondria in these cells. The disappointing negative results of the recent minocycline clinical trial in ALS [204] should not be construed as an outcome contradictory to the MPTP hypothesis, but rather as an example of the stark difficulty in interpreting the in vivo effects of a multifunctional drug in a disease process and the importance of identifying and selecting appropriate dosing regimens. One basic biologic explanation for the outcome of the minocycline-ALS trial is that neuronal cell death and inflammatory mechanisms in human and mice are different [144] and, thus, the effects of minocycline could differ. Further study of mitochondria and the mPTP in human and rodent neurons, glial cells, and skeletal myocytes can define new mechanisms of disease and can lead to the identification of molecular mechanism-based therapies for treating PD and ALS.

\section{APPENDUM}

We have shown recently that restricted expression of human SOD1 in skeletal muscle of Tg mice causes ALS with a motor neuron degeneration phenotype similar to that seen in human ALS [205].

\section{ACKNOWLEDGMENTS}

The author thanks all of the individuals in his lab for their hard work, particularly Yan Pan and Ann Price for data generated on human PD and ALS autopsy brain and spinal cord, the A53T $\alpha$-Syn Tg mouse, and the G93A-mSOD1 Tg mouse. This work was supported by grants from the U.S. Public Health Service, NIH-NINDS (NS065895, NS052098) and NIH-NIA (AG016282).

The author's disclosures available online (http:// www.j-alz.com/disclosures/view.php?id=361).

\section{REFERENCES}

[1] Zorov DB, Isave NK, Plotnikov EY, Zorova LD, Stelmashook EV, Vasileva AK, Arkhagelskaya AA, Khrjapenkova TG (2007) The mitochondrion as Janus Bifrons. Biochemistry (Moscow) 72, 1115-1126.

[2] Nicholls DG (2002) Mitochondrial function and dysfunction in the cell: its relevance to aging and aging-related disease. Intl J Biochem Cell Biol 34, 1372-1381.

[3] Wallace DC (2002) A mitochondrial paradigm of metabolic and degenerative diseases, aging, and cancer: a dawn of evolutionary medicine. Annu Rev Genet 39, 359-407.

[4] Fridovich I (1995) Superoxide radical and superoxide dismutases. Annu Rev Biochem 64, 97-112.

[5] Halliwell B (2001) Role of free radicals in the neurodegenerative diseases. Drugs Aging 18, 685-716.

[6] Mungrue IN, Bredt DS, Stewart DJ, Husain M (2003) From molecules to mammals: what's NOS got to do with it? Acta Physiol Scand 179, 123-135.

[7] Beckman JS, Carson M, Smith CD, Koppenol WH (1993) ALS, SOD and peroxynitrite. Nature 364, 548.

[8] Martin LJ, Liu Z (2002) DNA damage profiling in motor neurons: a single-cell analysis by comet assay. Neurochem Res 27, 1089-1100.

[9] Giulini C (2003) Characterization and function of mitochondrial nitric-oxide synthase. Free Radic Biol Med 34, 397-408.

[10] Brown GC, Borutaite V (1999) Nitric oxide, cytochrome c, and mitochondria. Biochem Soc Sym 66, 17-25.

[11] Delettre C, Lenaers G, Pelloquin L, Belenguer P, Hamel CP (2002) OPA1 (Kjer type) dominant optic atrophy: a novel mitochondrial disease. Mol Genet Metab 75, 97-107.

[12] Martin LJ, Al-Abdulla NA, Brambrink AM, Kirsch JR, Sieber FE, Portera-Cailliau C (1998) Neurodegeneration in excitotoxicity, global cerebral ischemia, and target deprivation: a perspective on the contributions of apoptosis and necrosis. Brain Res Bull 46, 281-309.

[13] Northington FJ, Graham EM, Martin LJ (2005) Apoptosis in perinatal hypoxic-ischemic brain injury: how important is it and should it be inhibited? Brain Res Rev 50, 244-257.

[14] Martin LJ (2010) The mitochondrial permeability transition pore: a molecular target for amyotrophic lateral sclerosis. Biochim Biophys Acta 1802, 186-197.

[15] Waldmeier PC, Zimmermann K, Qian T, Tintelnot-Blomley M, Lemasters JJ (2003) Cyclophilin D as a drug target. Curr Med Chem 10, 1485-1506.

[16] Crompton M (2004) Mitochondria and aging: a role for the permeability transition? Aging Cell 3, 3-6.

[17] Halestrap AP (2009) What is the mitochondrial permeability transition pore? J Mol Cell Cardiol 46, 821-831.

[18] Bernardi P, Krauskopf A, Basso E, Petronilli V, BlalchyDyson E, Di Lisa F, Forte MA (2006) The mitochondrial permeability transition from in vitro artifact to disease target. FEBS J 273, 2077-2099. 
[19] Van Den Eeden SK, Tanner CM, Bernstein AL, Fross RD, Leimpeter A, Bloch DA, Nelson LM (2003) Indicence of Parkinson's disease: variations by age, gender and race ethnicity. Am J Epidemol 157, 1015-1022.

[20] Jankovic J (2008) Parkinson's disease: clinical features and diagnosis. J Neurol Neurosurg Psychiatry 79, 368-376.

[21] Lowe J, Lennox G, Leigh PN (1997) Disorders of movement and system degeneration. In Greenfields Neuropathology, Graham DI, Lantos PL, eds. London: Arnold, pp. 281366.

[22] Braak H, Del Tredici K, Rüb U, d Vos RAI, Jansen Steur ENH, Braak E (2003) Staging of brain pathology related to sporadic Parkinson's disease. Neurobiol Aging 24, 197-211.

[23] Martin LJ (2002) Neurodegenerative disorders of the human brain and spinal cord. In Encyclopedia of the Human Brain; Ramachandran VS, ed. Elsevier Science, Volume 3, pp. 441463.

[24] Goedert M (2001) Alpha-synuclein and neurodegenerative diseases. Nat Rev Neurosci 2, 492-501.

[25] Schapira AHV (2006) Etiology of Parkinson's disease. Neurology 66 (Suppl 4), S10-S23.

[26] Ascherio A, Chen H, Weisskopf MG, O'Reilly E, McCullough ML, Calle EE, Schwarzchild MA, Thun MJ (2006) Pesticide exposure and risk for Parkinson's disease. Ann Neurol 60, 197-203.

[27] Shimohama S, Swada H, Kitamura, Y, Taniguchi T (2003) Disease model: Parkinson's disease. Trends Mol Med 9, 360365.

[28] Polymeropoulos MH, Lavedan C, Leroy E, Ide SE, Dehejia A, Dutra A, Pike B, Root H, Rubenstein J, Boyer R, Stenroos ES, Chandrasekharappa S, Athanassiadou A, Papapetropoulos T, Johnson WG, Lazzarini AM, Duvoisin RC, Di Iorio G, Golbe LI, Nussbaum RL (1997) Mutation in the $\alpha$-synuclein gene identified in families with Parkinson's disease. Science 276, 2045-2047.

[29] Singleton, AB, Farrer M, Johnson J, Singleton A, Hague S, Kachergus J, Hulihan M, Peuralinna T, Dutra A, Nussbaum R, Lincoln S, Crawley A, Hanson M, Maraganore D, Adler C, Cookson MR, Muenter M, Baptista M, Miller D, Blancato J, Hardy J, Gwinn-Hardy K (2003) Alpha-synuclein locus triplication causes Parkinson's disease. Science 302, 841.

[30] Leroy E, Boyer R, Auburger G, Leube B, Ulm G, Mezey E, Harta G, Browstein MJ, Jonnalagada S, Chernova T, Dehejia A, Lavedan C, Gasser T, Steinbach PJ, Wilkinson KD, Polymeropoulos MH (1998) The ubiquitin pathway in Parkinson's disease. Nature 395, 451-452.

[31] Bonifati V, Rizzu P, van Baren MJ, Schaap O, Breedveld GJ, Krieger E, Dekker MC, Squitieri F, Ibanez P, Joosse M, van Dongen JW, Vanacore N, van Swieten JC, Brice A, Meco G, van Duijn CM, Oostra BA, Heutink P (2003) Mutations in the DJ-1 gene associated with autosomal recessive early-onset parkinsonism. Science 299, 256-259.

[32] Hatano Y, Li Y, Sato K, Asakawa S, Yamamura Y, Tomiyama H, Yoshino H, Asahina M, Kobayashi S, Hassin-Baer S, Lu CS, Ng AR, Rosales PL, Shimizu N, Toda T, Mizuno Y, Hattori N (2004) Novel PINK1 mutations in early-onset parkinsonism. Ann Neurol 56, 424-427.

[33] Kitada T, Asakawa S, Hattori N, Matsumine H, Yamamura Y, Minoshima S, Yokochi M, Mizuno Y, Shimizu N (1998) Mutations in the parkin gene cause autosomal recessive juvenile parkinsonism. Nature 392, 605-608.

[34] Valente EM, Abou-Sleiman PM, Caputo V, Muqit MM, Harvey $\mathrm{K}$, Gispert A, Ali Z, Del Turco D, Bentivoglio AR, Healy DG, Albanese A, Nussbaum R, Gonzalez-Maldonado
R, Deller T, Salvi S, Cortelli P, Gilks WP, Latchman DS, Harvey RJ, Dallapiccola B, Auburger G, Wood NW (2004) Hereditary early-onset Parkinson's disease caused by mutations in PINK1. Science 304, 1158-1160.

[35] Paisán-Ruz C, Jain S, Whitney Evans E, Gilks WP, Simón J, van der Brug M, López de Munain A, Aparicio S, MartnezGil A, Khan N, Johnson J, Ruiz Martinez J, Nicholl D, Marti Carrera I, Saénz Peòa A, de Silva R, Lees A, Mart-Massó JF, Pérez-Tur J, Wood NW, Singleton AB (2004) Cloning of the gene containing mutations that cause PARK8-linked Parkinson's disease. Neuron 44, 595-600.

[36] Zimprich A, Biskup S, Leitner P, Lichtner P, Farrer M, Lincoln S, Kachergus J, Hulihan M, Uitti RJ, Calne DB, Stoessi J, Pfeiffer RF, Patenge N, Carballo Carbajal I, Vieregge P, Asmus F, Müller-Myhsok B, Dickson DW, Meitinger T, Storm TM, Wszolek ZK, Gasser T (2004) Mutations in LRRK2 cause autosomal-dominant parkinsonism with pleomorphic pathology. Neuron 44, 601-607.

[37] Ramirez A, Heimbach A, Grundemann J, Stiller B, Hampshire D, Cid LP, Goebel I, Mubaidin AF, Wriekat A-L, Roeper J, Al-Din A, Hillmer AM, Karsak M, Liss B, Woods CG, Behrens MI (2006) Hereditary parkinsonism with dementia is caused by mutations in ATP13A2, encoding a lysosomal type 5 P-type ATPase. Nat Genet 38, 1184-1191.

[38] Lesuisse C, Martin LJ (2002) Long-term culture of mouse cortical neurons as a model for neuronal development, aging, and death. J Neurobiol 51, 9-23.

[39] Maroteaux L, Campanelli JT, Scheller RH (1988) Synuclein: a neuron-specific protein localized to the nucleus and presynaptic nerve terminals. J Neurosci 8, 2804-2815.

[40] Murphy DD, Rueter SM, Trojanowski JQ, Lee VMY (2000) Synucleins are developmentally expressed, and $\alpha$-synuclein regulates the size of the presynaptic vesicular pool in primary hippocampal neurons. J Neurosci 20, 3214-3220.

[41] Chandra S, Fornai F, Kwon HB, Yazdani U, Atasoy D, Liu X, Hammer RE, Battaglia G, German DC, Castillo PE, Sudhof TC (2004) Double knockout mice for $\alpha$ - and $\beta$-synucleins: effect on synaptic functions. Proc Natl Acad Sci U S A 101, 14966-14971.

[42] Gurevicine I, Gurevicius K, Tanila H (2007) Role of $\alpha$ synuclein in synaptic glutamate release. Neurobiol Dis $\mathbf{2 8}$, 83-89.

[43] Liu S, Fa M, Ninan I, Trinchese F, Dauer W, Aranico O (2007) $\alpha$-Synuclein involvement in hippocampal synaptic plasticity: role of NO, cGMP, cGK and CAMKII. Eur J Neurosci 25, 3583-3596.

[44] Fortin DL, Nemani VM, Voglmaier SM, Anthony MD, Ryan TA, Edwards RH (2005) Neural activity control the synaptic accumulation of $\alpha$-synuclein. J Neurosci 25, 10913-10921.

[45] Chandra S, Gallardo G, Fernandez-Chacon R, Schluter OM, Sudholf TC (2005) $\alpha$-Synuclein cooperates with $\operatorname{CSP} \alpha$ in preventing neurodegeneration. Cell 123, 383-396.

[46] Gallardo G, Schluter OM, Sudhof TC (2008) A molecular pathway of neurodegeneration linking $\alpha$-synuclein to ApoE and A $\beta$ peptides. Nat Neurosci 11, 301-308.

[47] Serpell LC, Berriman J, Jakes M, Goedert M, Crowther RA (2000) Fiber diffraction of synthetic alpha synuclein filaments shows amyloid-like cross-beta conformation. Proc Natl Acad Sci U S A 97, 4897-4902.

[48] Conway KA, Lee SJ, Rochet JC, Ding TT, Williamson RE, Lansbury PT Jr (2000) Acceleration of oligomerization, not fibrilization, is a shared property of both alpha-synuclein mutations linked to early-onset Parkinson's disease: implications for pathogenesis and therapy. Proc Natl Acad Sci U 
$S A$ 97, 571-576.

[49] Caughey B, Lansbury PT (2003) Protofibrils, pores, fibril, and neurodegeneration: separating the responsible protein aggregates from the innocent bystanders. Annu Rev Neurosci 26, 267-298.

[50] Hsu LJ, Sagara Y, Arroyo A, Rockenstein E, Sisk A, Mallory M, Wong J, Takenouchi T, Hashimoto M, Masliah E (2000) Alpha-synuclein promotes mitochondrial deficit and oxidative stress. Am J Pathol 157, 401-410.

[51] Junn E, Mouradian MM (2002) Human $\alpha$-synuclein overexpression increases intracellular reactive oxygen species levels and susceptibility to dopamine. Neurosci Lett $\mathbf{3 2 0}$, 146-150.

[52] Tabrizi SJ, Orth M, Wilkinson JM, Taanman JW, Warner TT, Cooper JM, Schapira AH (2000) Expression of mutant alpha-synuclein causes increased susceptibility to dopamine toxicity. Hum Mol Genet 9, 2683-2689.

[53] Giasson BI, Duda JE, Quinn SM, Zhang B, Trojanowski JQ, Lee WM-Y (2002) Neuronal $\alpha$-synucleinopathy with severe movement disorder in mice expressing A53T human $\alpha$-synuclein. Neuron 34, 521-533.

[54] Giasson BI, Duda JE, Murray IVJ, Chen Q, Souza JM, Hurtig HI, Ischiropoulos H, Trojanowski JQ, Lee VM-Y (2000) Oxidative damage linked to neurodegeneration by selective alpha-synuclein nitration in synucleinopathy lesions. Science 290, 985-989.

[55] Ischiropoulos H (2003) Oxidative modification of alphasynuclein. Ann NY Acad Sci 991, 93-100.

[56] Wilkinson KD, Lee KM, Deshpande S, Duerken-Hughes P, Boss JM, Pohl J (1989) The neuron-specific protein PGP 9.5 is a ubiquitin carboxyl terminal hydrolase. Science $\mathbf{2 4 6}$, 670-673.

[57] Hershko A, Ciechanover A (1998) The ubiquitin system. Annu Rev Biochem 67, 425-479.

[58] Lansbury PT Jr, Brice A (2002) Genetics of Parkinson's disease and biochemical studies of implicated gene products. Curr Opin Cell Biol 14, 653-660.

[59] McNaught KS, Mytilineou C, Jnobaptiste R, Yabut J, Shahidharan P, Jennert P, Olanow CW (2002) Impairment of the ubiquitin-proteasome system causes dopaminergic cell death and inclusion body formation in ventral mesencephalic cultures. J Neurochem 81, 301-306.

[60] Imai Y, Takahashi R (2004) How do Parkin mutations result in neurodegeneration? Curr Opin Neurobiol 14, 384-389.

[61] Hattori N, Matsumine H, Asakawa S, Kitada T, Yoshino H, Elibol B, Brookes AJ, Yamamura Y, Kobayashi T, Wang M, Yoritaka A, Minoshima S, Shimizu N, Mizuno Y (1998) Point mutations (Thr240Arg and Gln311Stop) in the Parkin gene. Biochem Biophys Res Commun 249, 754-758.

[62] Beilina A, Van Der Brug M, Ahmad R, Kesavapany S, Miller DW, Petsko GA, Cookson MR (2005) Mutations in PTENinduced putative kinase 1 associated with recessive parkinsonism have differential effects on protein stability. Proc Natl Acad Sci U S A 102, 5703-5708.

[63] Silvestri L, Caputo V, Bellacchio E, Atorino L, Dallapiccola B, Valente EM, Casari G (2005) Mitochondrial import and enzymatic activity of PINK1 mutants associated to recessive parkinsonism. Hum Mol Genet 14, 3477-3492.

[64] Unoki M, Nakamura Y (2001) Growth-suppressive effects of BPOZ and RGR2, two genes involved in the PTEN signaling pathway. Oncogene 20, 4457-4465.

[65] Taymans J-M, Van den Haute C, Baekelandt V (2006) Distribution of PINK1 and LRRK2 in rat and mouse brain. $J$ Neurochem 98, 951-961.
[66] Weihofen A, Thomas KJ, Ostazewski BL, Cooksen MR, Selkoe DJ (2009) Pink1 forms a multiprotein complex with Miro and Milton, linking Pink1 function to mitochondrial trafficking. Biochemistry 48, 2045-2052.

[67] Deng H, Jankovic J, Guo Y, Xie W, Le W (2005) Small interfering RNA targeting the PINK1 induces apoptosis in dopaminergic cells SH-SY5Y. Biochem Biophys Res Commun 337, 1133-1138.

[68] Marongiu R, Spencer B, Crews L, Adame A, Patrick C, Trejo M, Dallapiccola B, Valente EM, Masliah E (2009) Mutant Pink1 induces mitochondrial dysfunction in a neuronal cell model of parkinson's disease by disturbing calcium flux. $J$ Neurochem 108, 1561-1574.

[69] Wilson MA, Collins JL, Hod Y, Ringe D, Petsko GA (2003) The 1.1-A resolution crystal structure of DJ-1, the protein mutated in autosomal recessive early onset Parkinson's disease. Proc Natl Acad Sci U S A 100, 9256-9261.

[70] Shang H, Lang D, Jean-Marc B, Kaelin-Lang A (2004) Localization of DJ-1 mRNA in the mouse brain. Neurosci Lett 367, 273-277.

[71] Canet-Aviles RM, Wilson MA, Miller DW, Ahmad R, McLendon C, Bandyopadhyay S, Baptista MJ, Ringe D, Petsko GA, Cookson MR (2004) The Parkinson's disease protein DJ-1 is neuroprotective due to cysteine-sulfinic acid-driven mitochondrial localization. Proc Natl Acad Sci U S A 101, 9103-9108.

[72] Miller DW, Ahmad R, Hague S, Baptista MJ, Canet-Aviles R, McLendon C, Carter DM, Zhu PP, Stadler J, Chandran J, Klinefelter GR, Blackstone C, Cookson MR (2003) L166P mutant DJ-1, causative for recessive Parkinson's disease, is degraded through the ubiquitin-proteasome system. J Biol Chem 278, 36588-36595.

[73] Takahashi-Niki K, Niki T, Taira T, Iguchi-Ariga SM, Ariga H (2004) Reduced anti-oxidative stress activities of DJ-1 mutants found in Parkinson's disease patients. Biochem Biophys Res. Commun 320, 389-397.

[74] Galter D, Westerlund M, Carmine A, Lindqvist E, Sydow O, Olson L (2006) LRRK2 expression linked to dopamineinnervated areas. Ann Neurol 59, 714-719.

[75] Melrose H, Lincoln S, Tyndall G, Dickson D, Farrer M (2006) Anatomical localization of leucine-rich repeat kinase 2 mouse brain. Neuroscience 139, 791-794.

[76] Iaccarino C, Crosio C, Vitale C, Sanna G, Carri MT, Barone $\mathrm{P}$ (2007) Apoptotic mechanisms in mutant LRRK2-mediated cell death. Hum Mol Gen 16, 1319-1326.

[77] Ho C C-Y, Rideout HJ, Ribe E, Troy CM, Dauer WT (2009) The Parkinson's disease protein leucine-rich repeat kinase 2 transduces death signals via Fas-associated protein with death domain and caspase- 8 in a cellular model of neurodegeneration J Neurosci 29, 1011-1016.

[78] Goldberg MS, Fleming SM, Palacino JJ, Capedam C, Lam HA, Bhatnagar A, Meloni EG, Wu N, Ackerson LC, Klapstein GJ, Gajendiram M, Roth BL, Chesselet MF, Maidment NT, Levine MS, Shen J (2003) Parkin-deficient mice exhibit nigrostriatal deficits but not loss of dopaminergic neurons. $J$ Biol Chem 278, 43628-43635.

[79] Perez FA, Palmiter RD (2005) Parkin-deficient mice are not a robust model of parkinsonism. Proc Natl Acad Sci U S A 102, 2174-2179.

[80] Palacino JJ, Sagi D, Goldberg MS, Krauss S, Motz C, Wacker M, Klose J, Shen J (2004) Mitochondrial dysfunction and oxidative damage in parkin-deficient mice. J Biol Chem $\mathbf{2 7 9}$, 18614-18622.

[81] Chen L, Cagniard B, Mathews T, Jones S, Koh HC, Ding Y, 
Carvey PM, Ling Z, Kang UJ, Zhuang X (2005) Agedependent motor deficits and dopaminergic dysfunction in DJ-1 null mice. J Biol Chem 280, 21418-21426.

[82] Goldberg MS, Pisani A, Haburcak M, Vortherms TA, Kitada Y, Costa C, Tong Y, Martella G, Tscherter A, Martins A, Bernardi G, Roth BL, Pothos EN, Calabresi P, Shen J (2005) Nigrostriatal dopaminergic deficits and hypokinesia caused by inactivation of the familial parkinsonism-linked gene DJ1. Neuron 45, 489-496.

[83] Lu X-H, Fleming SM, Meurers B, Ackerson LC, Mortazavi F, Lo V, Hernandez D, Sulzer D, Jackson GR, Maidment NT, Chesselet M-F, Yang XW (2009) Bacterial artificial chromosome transgenic mice expressing a truncated mutant Parkin exhibit age-dependent hypokinetic motor deficits, dopaminergic neuron degeneration, and accumulation of proteinase K-resistant $\alpha$-synuclein. J Neurosci 29, 1962-1976.

[84] Gispert S, Del Turco D, Garrett L, Chen A, Bernard DJ, Hamm-Clement J, Korf HW, Deller T, Braak H, Auburger G, Nussbaum RL (2003) Transgenic mice expressing mutant A53T human alpha-synuclein show neuronal dysfunction in the absence or aggregate formation. Mol Cell Neurosci 24, 419-429.

[85] Kahle PJ, Neumann M, Ozmen L, Muller V, Jacobsen $\mathrm{H}$, Schindzielorz A, Okochi M, Leimer U, van der Putten H, Probst A, Kremmer E, Kretzschmar HA, Haassm C (2000) Subcellular localization of wild-type and Parkinson's disease-associated mutant alpha-synuclein in human and transgenic mouse brain. J Neurosci 20, 6365-6373.

[86] Lee MK, Stirling W, Xu Y, Xu X, Qui D, Mandir AS, Dawson TM, Copeland NG, Jenkins NA, Price DL (2002) Human $\alpha$ synuclein-harboring familial Parkinson's disease-linked Ala$53 \rightarrow$ Thr mutation causes neurodegenerative disease with $\alpha$-synuclein aggregation in transgenic mice. Proc Natl Acad Sci U S A 99, 8968-8973.

[87] Masliah E, Rockenstein E, Veinbergs I, Mallory M, Hashimoto M, Takeda A, Sagara Y, Sisk A, Mucke L (2000) Dopaminergic loss and inclusion body formation in $\alpha$-synuclein mice: implications for neurodegenerative disorders. Science $\mathbf{2 8 7}$ 1265-1269.

[88] Richfield EK, Thiruchelvam MJ, Cory-Slechta DA, Wuetzer C, Gainetdinov RR, Caron MG, Di Monte DA, Federoff HJ (2002) Behavioral and neurochemical effects of wild-type and mutated human alpha-synuclein in transgenic mice. Exp Neurol 175, 35-48.

[89] van der Putten H, Wiederhold K-H, Probst A, Barbieri S, Mistl C, Danner S, Kauffmann S, Hofele K, Spooren WP, Ruegg MA, Lin S, Caroni P, Sommer B, Tolnay M, Bilbe G (2000) Neuropathology in mice expressing human $\alpha$ synuclein. J Neurosci 20, 6021-6029.

[90] Wakamatsu M, Ishii A, Iwata S, Sakagami J, Ukai Y, Ono M, Kanbe D, Muramatsu S-I, Kabayashi K, Iwatsubo T, Yoshimoto M (2008) Selective loss of nigral dopamine neurons induced by overexpression of truncated human $\alpha$-synuclein. Neurobiol Aging 29, 547-585.

[91] Martin LJ, Pan Y, Price AC, Sterling W, Copeland NG, Jenkins NA, Price DL, Lee MK (2006) Parkinson's disease $\alpha$ synuclein transgenic mice develop neuronal mitochondrial degeneration and cell death. $J$ Neurosci $\mathbf{2 6}, 41-50$.

[92] Lieberman AR (1971) The axon reaction: a review of the principal features of perikaryal responses to axon injury. Int Rev Neurobiol 14, 49-124.

[93] Poon HF, Frasier M, Shreve N, Calabrese V, Wolozin B, Butterfield DA (2005) Mitochondrial associated metabolic proteins are selectively oxidized in $\mathrm{A} 30 \mathrm{P} \alpha$-synuclein transgenic mice- a model of familial Parkinson's disease. Neurobiol Dis 18, 492-498.

[94] Turnbull S, Tabner BJ, El-Agnaf OM, Moore S, Davies Y, Allsop D (2001) Alpha-synuclein implicated in Parkinson's disease catalyses the formation of hydrogen peroxide in vitro. Free Radic Biol Med 30, 1163-1170.

[95] Tabrizi SJ, Orth M, Wilkinson JM, Taanman JW, Warner TT, Cooper JM, Schapira AH (2000) Expression of mutant alpha-synuclein causes increased susceptibility to dopamine toxicity. Hum Mol Genet 9, 2683-2689.

[96] Paxinou E, Chen Q, Weisse M, Giasson BI, Norris EH, Rueter SM, Trojanowski JQ, Lee VM-Y, Ischiropoulos H (2001) Induction of alpha-synuclein aggregation by intracellular nitrative insult. J Neurosci 21, 8053-8061.

[97] Souza JM, Giasson BI, Chen Q, Lee VM-Y, Ischiropoulos H (2000) Dityrosine cross-linking promotes formation of stable $\alpha$-synuclein polymers. J Biol Chem 265, 18344-18349.

[98] Martin LJ, Liu Z, Chen K, Price AC, Pan Y, Swaby JA, Golden WC (2007) Motor neuron degeneration in amyotrophic lateral sclerosis mutant superoxide dismutase- 1 transgenic mice: mechanisms of mitochondriopathy and cell death. $J$ Comp Neurol 500, 20-46.

[99] Chen K, Northington FJ, Martin LJ (2010) Inducible nitric oxide synthase is present in motor neuron mitochondria and Schwann cells and contributes to disease mechanisms in ALS mice. Brain Struct Funct 214, 219-234.

[100] Rowland LP, Shneider NA (2001) Amyotrophic lateral sclerosis. $N$ Engl J Med 344, 1688-1700.

[101] Sathasivam S, Ince PG, Shaw PJ (2001) Apoptosis in amyotrophic lateral sclerosis: a review of the evidence. $\mathrm{Neu}$ ropathol Appl Neurobiol 27, 257-274.

[102] Stephens B, Guiloff RJ, Navarrete R, Newman P, Nikhar $\mathrm{N}$, Lewis $\mathrm{P}$ (2006) Widespread loss of neuronal populations in spinal ventral horn in sporadic motor neuron disease. A morphometric study. J Neurol Sci 244, 41-58.

[103] Maekawa S, Al-Sarraj S, Kibble M, Landau S, Parnavelas J, Cotter D, Everall I, Leigh PN (2004) Cortical selective vulnerability in motor neurons disease: a morphometric study. Brain 127, 1237-1251.

[104] Zoccolella S, Santamato A, Lamberti P (2009) Current and emerging treatments for amyotrophic lateral sclerosis. Neuropsychiatr Dis Treat 5, 577-595.

[105] Kabashi E, Valdmains PN, Dion P, Spiegelman D, McConkey BJ, Vande Velde C, Bouchard J-P, Lacomblez L, Pochigaeva K, Salachas F, Pradat P-F, Camu W, Meininger V, Dupre N, Rouleau GA (2008) TARDBP mutations in individuals with sporadic and familial amyotrophic lateral sclerosis. Nat Genet 40, 572-574.

[106] Deng H-X, Hentati A, Tainer JA, Iqbal Z, Cayabyab A, Hung W-Y, Getzoff ED, Hu, P, Herzfeldt B, Roos RP, Warner C, Deng G, Soriano E, Smyth C, Parge HE, Ahmed A, Roses AD, Hallewell RA, Pericak-Vance MA, Siddique T (1993) Amyotrophic lateral sclerosis and structural defects in $\mathrm{Cu}, \mathrm{Zn}$ superoxide dismutase. Science 261, 1047-1051.

[107] Vance C, Rogelj B, Hortobagyi T, de Vos KJ, Nishimura AL, Sreedharan J, Hu X, Smith B, Ruddy D, Wright P, Ganesaligam J, Williams KL, Tripathi V, Saraj S, Al-Chalabi, A, Leigh N, Blair IP, Nicholson G, de Belleroche J, Gallo J-M, Miller CC, Shaw CE (2009) Mutations in FUS, an RNA processing protein, cause familial amyotrophic lateral sclerosis type 6. Science 323, 1208-1211.

[108] Schymick JC, Talbot K, Traynor GJ (2007) Genetics of amyotrophic lateral sclerosis. Hum Mol Genet 16, R233-R242.

[109] Chow CY, Lander JE, Bergren SK, Sapp PC, Grant AE, Jones 
JM, Everett L, Lenk GM, McKenna-Yasek DM, Weisman LS, Figlewicz D, Brown RH, Meisler MH (2009) Deleterious variants of FIG4, a phosphoinositade phosphatase, in patients with ALS. Am J Human Gen 84, 85-88.

[110] Sasaki S, Iwata M (1999) Ultrastructural changes of synapses of Betz cell in patients with amyotrophic lateral sclerosis. Neurosci Lett 268, 29-32.

[111] Menzies FM, Ince PG, Shaw PJ (2002) Mitochondrial involvement in amyotrophic lateral sclerosis. Neurochem Intl 40, 543-551.

[112] Comi GP, Bordoni A, Salani S, Franeschina L, Sciacco, M, Prelle A, Fortunato F, Zeviani M, Napoli L, Bresolin N, Moggio M, Ausenda CD, Taanman JW, Scarlato G (1998) Cytochrome $\mathrm{c}$ oxidase subunit I microdeletion in a patient with motor neuron disease. Ann Neurol 43, 110-116.

[113] Borthwick GM, Taylo RW, Walls TJ, Tonska K, Taylor GA, Shaw PJ, Ince PG, Turnbull DM (2006) Motor neuron disease in a patient with a mitochondrial tRNAIle mutation. Ann Neurol 59, 570-574.

[114] Soong NW, Hinton DR, Cortopassi G, Arnheim N (1992) Mosaicism for a specific somatic mitochondrial DNA mutation in adult human brain. Nat Genet 2, 318-323.

[115] Corral-Debrinski M, Horton T, Lott MT, Shoffner JM, Beal MF, Wallace DC (1992) Mitochondrial DNA deletions in human brain: regional variability and increase with advanced age. Nat Genet 2, 324-329.

[116] Mawrin C, Kirches E, Krause G, Wiedemann FR, Vorwerk CK, Bogerts B, Schildhaus HU, Dietzmann K, SchneiderStock R (2004) Single-cell analysis of mtDNA levels in sporadic amyotrophic lateral sclerosis. NeuroReport 15, 939943.

[117] Bender A, Krishnan KJ, Morris CM, Taylor GA, Reve AK, Perry RP, Jaros E, Hersheson JS, Betts J, Klopstock T, Taylor RW, Turnbull DM (2006) High levels of mitochondrial DNA deletions in substantia nigra neurons in aging and Parkinson's disease. Nat Genet 38, 515-517.

[118] Kraytsberg Y, Kudryavtseva E, McKee AC, Geula C, Kowall NW, Khrapko K (2006) Mitochondrial DNA deletions are abundant and cause functional impairment in aged human substantia nigra neurons. Nat Genet 38, 518-520.

[119] Babcock D, Hille B (1998) Mitochondrial oversight of cellular $\mathrm{Ca}^{2+}$ signaling. Curr Opin Neurobiol 8, 398-404.

[120] Siklos L, Engelhardt J, Harat Y, Smith RG, Joo F, Appel SH (1996) Ultrastructural evidence for altered calcium in motor nerve terminals in amyotrophic lateral sclerosis. Ann Neurol 39, 203-216.

[121] Zoratti M, Szabo I (1995) The mitochondrial permeability transition. Biochem Biophys Acta 1241, 139-176.

[122] Olney JW (1971) Glutamate-induced neuronal necrosis in the infant mouse hypothalamus. An electron microscopic study. J Neuropathol Exp Neurol 30, 75-90.

[123] Choi DW (1992) Excitotoxic cell death. J Neurobiol 23, 1261-1276.

[124] Choi DW (2005) Cellular defences destroyed. Nature 433, 696-698.

[125] Brown MR, Sullivan PG, Geddes JW (2006) Synaptic mitochondria are more susceptible to $\mathrm{Ca}^{2+}$ overload than nonsynaptic mitochondria. J Biol Chem 281, 11658-11668.

[126] Rothstein JD, Martin LJ, Kuncl RW (1992) Decreased glutamate transport by brain and spinal cord in amyotrophic lateral sclerosis. N Engl J Med 326, 1464-1468.

[127] Rothstein JD, Van Kammen M, Levey AI, Martin LJ, Kuncl RW (1995) Selective loss of glial glutamate transporter GLT1 in amyotrophic lateral sclerosis. Ann Neurol 38, 73-84.
[128] Heath PR, Tomkins J, Ince PG, Shaw PJ (2002) Quantitative assessment of AMPA receptor mRNA in human spinal motor neurons isolated by laser capture microdissection. NeuroReport 13, 1753-1757.

[129] Kwak S, Kawahara Y (2005) Deficient RNA editing of GluR2 and neuronal death in amyotrophic lateral sclerosis. $J \mathrm{Mol}$ Med 83, 110-120.

[130] Chang DTW, Reynolds IJ (2006) Mitochondrial trafficking and morphology in healthy and injured neurons. Prog Brain Res 80, 241-268.

[131] Hansson MJ, Mansson R, Morota S, Uchino H, Kallur T, Sumi T, Ishii N, Shimazu M, Keep MF, Jegorov A, Elmer E (2008) Calcium-induced generation of reactive oxygen species in brain mitochondria is mediated by permeability transition. Free Radic Biol Med 45, 284-294.

[132] Bergmann F, Keller BU (2004) Impact of mitochondrial inhibition on excitability and cytosolic $\mathrm{Ca}^{2+}$ levels in brainstem motoneurones. J Physiol 555, 45-59.

[133] Beal MF (2002) Oxidatively modified protein in aging and disease. Free Radic Biol Med 32, 797-803.

[134] Ferrante RJ, Browne SE, Shinobu LA, Bowling AC, Baik MJ, MacGarvey U, Kowall NW, Brown Jr RH, Beal MF (1997) Evidence of increased oxidative damage in both sporadic and familial amyotrophic lateral sclerosis. J Neurochem 69, 2064-2074.

[135] Abe K, Pan L-H, Watanabe M, Kato T, Itoyama Y (1995) Induction of nitrotyrosine-like immunoreactivity in the lower motor neuron of amyotrophic lateral sclerosis. Neurosci Lett 199, 152-154.

[136] Beal MF, Ferrante RJ, Browne SE, Matthews RT, Kowall NW, Brown Jr RH (1997) Increased 3-nitrotyrosine in both sporadic and familial amyotrophic lateral sclerosis. Ann $\mathrm{Neu}$ rol 42, 644-654.

[137] Sasaki S, Warita H, Abe K, Iwata M (2001) Inducible nitric oxide synthase (iNOS) and nitrotyrosine immunoreactivity in the spinal cords of transgenic mice with mutant SOD1 gene. J Neuropathol Exp Neurol 60, 839-846.

[138] Browne SE, Bowling AC, Baik MJ, Gurney M, Brown Jr RH, Beal MF (1998) Metabolic dysfunction in familial, but not sporadic, amyotrophic lateral sclerosis. J Neurochem 71, 281-287.

[139] Borthwick GM, Johnson MA, Ince PG, Shaw PJ, Turnbull DM (1999) Mitochondrial enzyme activity in amyotrophic lateral sclerosis: implications for the role of mitochondria in neuronal cell death. Ann Neurol 46, 787-790.

[140] Vielhaber S, Kunz D, Winkler K, Wiedemann FR, Kirches E, Feistner H, Heinze HJ, Elger CE, Schubert W, Kunz WS (2000) Mitochondrial DNA abnormalities in skeletal muscle of patients with sporadic amyotrophic lateral sclerosis. Brain 123, 1339-1348.

[141] Soraru G, Vergani L, Fedrizzi L, D’Ascenzo C, Polo A, Bernazzi B, Angelini C (2007) Activities of mitochondrial complexes correlate with nNOS amount in muscle from ALS patients. Neuropath Appl Neurobiol 33, 204-211

[142] Echaniz-Laguna A, Zoll J, Ponsot E, N'Guessan B, Tranchant C, Loeffler J-P, Lampert E (2006) Muscular mitochondrial function in amyotrophic lateral sclerosis is progressively altered as the disease develops: a temporal study in man. Exp Neurol 198, 25-30.

[143] Martin LJ (1999) Neuronal death in amyotrophic lateral sclerosis is apoptosis: possible contribution of a programmed cell death mechanism. J Neuropathol Exp Neurol 58, 459-471.

[144] Martin LJ, Liu Z (2004) Opportunities for neuroprotection in ALS using cell death mechanism rationales. Drug Discov 
Today 1, 135-143.

[145] Ginsberg SD, Hemby SE, Mufson EJ, Martin LJ (2006) Cell and tissue microdissection in combination with genomic and proteomic profiling. In Neuroanatomical Tract-Tracing 3, Molecules, Neurons, and Systems; Zaborszky L, Wouterlood FG, Lanciego JL, eds. Springer: New York, pp. 109-141.

[146] Martin LJ (2000) p53 is abnormally elevated and active in the CNS of patients with amyotrophic lateral sclerosis. Neurobiol Dis 7, 613-622.

[147] Martin LJ (2001) Neuronal cell death in nervous system development, disease, and injury. Int J Mol Med 7, 455-478.

[148] Martin LJ, Kaiser A, Price AC (1999) Motor neuron degeneration after sciatic nerve avulsion in adult rat evolves with oxidative stress and is apoptosis. J Neurobiol 40, 185-201.

[149] Martin LJ, Liu Z (2002) Injury-induced spinal motor neuron apoptosis is preceded by DNA single-strand breaks and is p53- and Bax-dependent. J Neurobiol 50, 181-197.

[150] Fornai F, Longone P, Ferrucci M, Lenzi P, Isidoro C, Ruggieri S, Paparelli A (2008) Autophagy and amyotrophic lateral sclerosis. Autophagy 4, 527-530.

[151] Turner BJ, Talbot K (2008) Transgenics, toxicity and therapeutics in rodent models of mutant SOD1-mediated familial ALS. Prog Neurobiol 85, 94-134.

[152] McCord JM, Fridovich I (1969) Superoxide dismutase, an enzymic function for erythrocuprein (hemocuprein). $J$ Biol Chem 244, 6049-6055.

[153] Rakhit, R, Crow JP, Lepock JR, Kondejewski LH, Cashman NR, Chakrabartty A (2004) Monomeric Cu, Zn-superoxide dismutase is a common misfolding intermediate in the oxidation models of sporadic and familial amyotrophic sclerosis. J Biol Chem 279, 15499-15504.

[154] Ferri A, Cozzolino M, Crosio C, Nencini M, Casciati A, Gralla EB, Rotilio G, Valentine JS, Carri MT (2006) Familial ALS-superoxide dismutases associate with mitochondria and shift their redox potentials. Proc Natl Acad Sci U S A 103, 13860-13865.

[155] Estévez AG, Crow JP, Sampson JB, Reiter C, Zhuang Y, Richardson GJ, Tarpey L, Barbeito MM, Beckman JS (1999) Induction of nitric oxide-dependent apoptosis in motor neurons by zinc-deficient superoxide dismutase. Science $\mathbf{2 8 6}$, 2498-2500.

[156] Flanagan SW, Anderson RD, Ross MA, Oberley LW (2002) Overexpression of manganese superoxide dismutase attenuates neuronal death in human cells expressing mutant (G37R) $\mathrm{Cu} / \mathrm{Zn}$-superoxide dismutase. J Neurochem 81, 170-177.

[157] Bilsland LG, Nirmalananthan N, Yip J, Greensmith L, Duhcen MR (2008) Expression of mutant SOD1G93A in astrocytes induces functional deficits in motoneuron mitochondria. J Neurochem 107, 1271-1283.

[158] Gurney ME, Pu H, Chiu AY, Dal Canto MC, Polchow CY, Alexander DD, Caliendo J, Hentati A, Kwon YW, Deng HX, Chen W, Zhai P, Sufit RL, Siddique T (1994) Motor neuron degeneration in mice that express a human $\mathrm{Cu}, \mathrm{Zn}$ superoxide dismutase mutation. Science 264, 1772-1775.

[159] Dal Canto MC, Gurney ME (1994) Development of central nervous system pathology in a murine transgenic model of human amyotrophic lateral sclerosis. Am J Pathol 145, 12711279.

[160] Martin LJ, Gertz B, Pan Y, Price AC, Molkentin JD, Chang $\mathrm{Q}$ (2009) The mitochondrial permeability transition pore in motor neurons: involvement in the pathobiology of ALS mice. Exp Neurol 218, 33-346.

[161] Chang Q, Martin LJ (2009) Glycinergic innervation of motoneurons is deficient in amyotrophic lateral sclerosis mice: a confocal quantitative analysis. Am J Pathol 174, 574-585.

[162] Bendotti C, Calvaresi N, Chiveri L, Prelle A, Moggio M, Braga M, Silani V, De Biasi S (2001) Early vacuolization and mitochondrial damage in motor neurons of FALS mice are not associated with apoptosis or with changes in cytochrome oxidase histochemical reactivity. J Neurol Sci 191, 25-33.

[163] Wong PC, Pardo CA, Borchelt DR, Lee MK, Copeland NG, Jenkins NA, Sisodia SS, Cleveland DW, Price DL (1995) An adverse property of a familial ALS-linked SOD1 mutation causes motor neuron disease characterized by vacuolar degeneration of mitochondria. Neuron 14, 1105-1116.

[164] Kong J, Xu Z (1998) Massive mitochondrial degeneration in motor neurons triggers the onset of amyotrophic lateral sclerosis in mice expressing a mutant SOD1. J Neurosci $\mathbf{1 8}$, 3241-3250.

[165] Jaarsma D, Rognoni F, van Duijn W, Verspaget HW, Haasdijk ED, Holstege JC (2001) CuZn superoxide dismutase (SOD1) accumulates in vacuolated mitochondria in transgenic mice expressing amyotrophic lateral sclerosis-linked SOD1 mutations. Acta Neuropathol 102, 293-305.

[166] Sasaki S, Warita H, Murakami T, Abe K, Iwata M (2004) Ultrastructural study of mitochondria in the spinal cord of transgenic mice with a G93A mutant SOD1 gene. Acta Neuropathol 107, 461-474.

[167] Borchelt DR, Lee MK, Slunt HH, Guarnieri M, Xu Z-S, Wong PC, Brown Jr R.H, Price DL, Sisodia SS, Cleveland DW (1994) Superoxide dismutase 1 with mutations linked to familial amyotrophic lateral sclerosis possesses significant activity. Proc Natl Acad Sci U S A 91, 8292-8296.

[168] Yim MB, Kang J-H, Yim H-S, Kwak H-S, Chock PB, Stadtman ER (1996) A gain-of- function of an amyotrophic lateral sclerosis-associated $\mathrm{Cu}, \mathrm{Zn}$-superoxide dismutase mutant: an enhancement of free radical formation due to a decrease in $\mathrm{K}_{m}$ for hydrogen peroxide. Proc Natl Acad Sci U S A 93, 5709-5714.

[169] Kabashi E, Valdmanis PN, Dion P, Rouleau GA (2007) Oxidized/misfolded superoxide dismutase-1: the cause of all amyotrophic lateral sclerosis? Ann Neurol 62, 553-559.

[170] Ezzi SA, Urushitani M, Julien J-P (2007) Wild-type superoxide dismutase acquires binding and toxic properties of ALSlinked mutant forms through oxidation. J Neurochem 102, 170-178.

[171] Liochev SI, Fridovich I (2003) Mutant Cu,Zn superoxide dismutases and familial amyotrophic lateral sclerosis: evaluation of oxidative hypotheses. Free Radic Biol Med 34, 13831389.

[172] Pacher P, Beckman JS, Liaudet L (2007) Nitric oxide and peroxynitrite in health and disease. Physiol Rev 87, 315-424.

[173] Andrus PK, Fleck TJ, Gurney ME, Hall ED (1998) Protein oxidative damage in a transgenic mouse model of familial amyotrophic lateral sclerosis. J Neurochem 71, 2041-2048.

[174] Poon HF, Hensley K, Thongboonkerd V, Merchant ML, Lynn BC, Pierce WM, Klein JB, Calabrese V, Butterfield DA (2005) Redox proteomics analysis of oxidatively modified proteins in G93A-SOD1 transgenic mice- a model of familial amyotrophic lateral sclerosis. Free Radic Biol Med 39, 435-462.

[175] Okado-Matsumoto A, Fridovich I (2001) Subcellular distribution of superoxide (SOD) in rat liver. J Biol Chem 276, 38388-38393.

[176] Higgins CMJ, Jung C, Ding $\mathrm{H}, \mathrm{Xu} \mathrm{Z}$ (2002) Mutant Cu, $\mathrm{Zn}$ Superoxide dismutase that causes motoneuron degeneration is present in mitochondria in the CNS. J Neurosci 22, RC215:1-6. 
[177] Pasinelli P, Belford ME, Lennon N, Bacskai BJ, Hyman BT, Trotti D, Brown Jr RH (2004) Amyotrophic lateral sclerosisassociated SOD1 mutant protein bind and aggregate with Bcl-2 in spinal cord mitochondria. Neuron 43, 19-30.

[178] Vande Velde C, Miller TM, Cashman NR, Cleveland DW (2008) Selective association of misfolded ALS-linked mutant SOD1 with the cytoplasmic face of mitochondria. Proc Natl Acad Sci U S A 105, 4022-4027.

[179] Goldsteins G, Keksa-Goldsteine V, Ahtiniemi T, Jaronen M, Arens E, Akerman K, Chan RH, Koistinaho J (2008) Deleterious role of superoxide dismutase in the mitochondrial intermembrane space. J Biol Chem 283, 8446-8452.

[180] Higgins CM, Jung C, Xu Z (2003) ALS-associated mutant SOD1G93A causes mitochondrial vacuolation by expansion of the intermembrane space and by involvement of SOD1 aggregation and peroxisomes. BMC Neurosci 4, 16.

[181] De Vos KJ, Chapman AL, Tennant ME, Manser C, Tudor EL, Lau K-F, Browlees J, Ackerley S, Shaw PJ, McLoughlin DM, Shaw CE, Leigh PN, Miller CCJ, Grierson AJ (2007) Familial amyotrophic lateral sclerosis-linked SOD1 mutants perturb fast axonal transport to reduce axonal mitochondrial content. Hum Mol Genet 16, 2720-2728.

[182] Martin LJ, Chen K, Liu Z (2005) Adult motor neuron apoptosis is mediated by nitric oxide and Fas death receptor linked by DNA damage and p53 activation. J Neurosci 25, 64496459

[183] Siklos L, Engelhardt JI, Alexianu ME, Gurney ME, Siddique T, Appel SH (1998) Intracellular calcium parallels motoneuron degeneration in SOD-1 mutant mice. J Neuropath Exp Neurol 57, 571-587.

[184] Jaiswal MK, Keller BU (2009) Cu/Zn superoxide dismutase typical for familial amyotrophic lateral sclerosis increases the vulnerability of mitochondria and perturbs $\mathrm{Ca}^{2+}$ homeostasis in SOD1 ${ }^{G 93 A}$ mice. Mol Pharmacol 75, 478-489.

[185] Nguyen KT, Garcia-Chacon LE, Barrett JN, Barrett EF, David G (2009) The $\psi_{m}$ depolarization that accompanies mitochondrial $\mathrm{Ca}^{2+}$ uptake is greater in mutant SOD1 than in wild-type mouse motor terminals. Proc Natl Acad Sci USA 106, 2007-2011.

[186] Sasaki S, Shibata N, Komori T, Iwata M (2000) iNOS and nitrotyrosine immunoreactivity in amyotrophic lateral sclerosis. Neurosci Lett 291, 44-48.

[187] Martin LJ (2010) Mitochondrial and cell death mechanisms in neurodegenerative diseases. Pharmaceuticals 3, 839-915.

[188] Kunz WS (2003) Different metabolic properties of mitochondrial oxidative phosphorylation in different cell types- important implications for mitochondrial cytopathies. Exp Physiol 88, 149-154.

[189] Keep M, Elmér E, Fong KSK, Csiszar K (2001) Intrathecal cyclosporin prolongs survival of late-stage ALS mice. Brain Res 894, 27-331.

[190] Karlsson J, Fong KS, Hansson MJ, Elmer E, Csiszar K, Keep MF (2004) Life span extension and reduced neuronal death after weekly intraventricular cyclosporine injections in the G93A transgenic mouse model of amyotrophic lateral sclerosis. J Neurosurg 101, 128-137.

[191] Kirkinezos IG, Hernandez, Bradley WG, Moraes CT (2004) An ALS mouse model with a permeable blood-brain barrier benefits from systemic cyclosporine A treatment. $\mathrm{J} \mathrm{Neu}$ rochem $\mathbf{8 8}, 821-826$.

[192] Bordet T, Buisson B, Michaud M, Drouot C, Galea P, Delaage P, Akentieva NP, Evers AS, Covey DF, Ostuni MA, lacapere JJ-J, Massaad C, Schmacher M, Steidl E-M, Maux D, Delaage M, Henderson CE, Pruss RM (2007) Identification and characterization of Cholest-4-en-3-one, oxime (TRO19622), a novel drug candidate for amyotrophic lateral sclerosis. $J$ Pharmacol Exp Ther 322, 709-720.

[193] Mills C, Makwana M, Wallace A, Benn S, Schmidt H, Tegeder I, Costigan M, Brown Jr RH, Raivich G, Woolf C (2008) Ro5-4864 promotes neonatal motor neuron survival and nerve regeneration in adult rats. Eur J Neurosci 27, 937 946.

[194] Yan L-J, Sohal RS (1998) Mitochondrial adenine nucleotide translocase is modified oxidatively during aging. Proc Natl Acad Sci U S A 95, 12896-12901.

[195] Prokai L, Yan L-J, Vera-Serrano JL, Stevens Jr SM, Forster MJ (2007) Mass spectrometry-based survey of ageassociated protein carbonylation in rat brain mitochondria. $J$ Mass Spectrom 42, 1583-1589.

[196] Vieira HLA, Belzacq A-S, Haouzu D, Bernassola F, Cohen I, Jacotot E, Ferri KF, Hamel CE, Bartle LM, Melino G, Brenner C, Goldmacher V, Kroemer G (2001) The adenine nucleotide translocator: a target of nitric oxide, peroxynitrite, and 4-hydroxynonenal. Oncogene 20, 4305-4316.

[197] McStay GP, Clarke SJ, Halestrap AP (2002) Role of critical thiol groups on the matrix surface of the adenine nucleotide translocase in the mechanism of the mitochondrial permeability transition pore. Biochem J 367, 541-548.

[198] Costantini P, Belzacq A-S, Vieira HLA, Larochette N, de Pablo MA, Zamzami N, Susin SA, Brenner C, Kroemer G (2000) Oxidation of a critical thiol residue of the adenine nucleotide translocator enforces Bcl-2-independent permeability transition pore opening and apoptosis. Oncogene 19, 307-314.

[199] García N, Martínez-Abundis E, Pavón N, Correa F, Chávez E (2007) Copper induces permeability transition through its interaction with the adenine nucleotide translocase. Cell Biol Int 31, 893-899.

[200] Grimm S, Brdiczka D (2007) The permeability transition pore in cell death. Apoptosis 12, 841-855.

[201] Du H, Guo L, Fang F, Chen D, Sosunov AA, McKhann GM, Yan Y, Wang C, Zhang H, Molkentin JD, Gunn-Moore FJ, Vonsattel JP, Aranico O, Chen JX, Yan SD (2008) Cyclophilin $\mathrm{D}$ deficiency attenuates mitochondrial and neuronal perturbation and ameliorates learning and memory in Alzheimer's disease. Nat Med 14, 1097-1105.

[202] Forte M, Gold BG, Marracci G, Chaudhary P, Basso E, Johnsen D, Yu Z, Fowlkes J, Rahder M, Stern K, Bernardi P, Bourdette D (2007) Cyclophilin D inactivation protects axons in experimental autoimmune encephalomyelitis, an animal model of multiple sclerosis. Proc Natl Acad Sci U S A 104, 7558-7563.

[203] Schinzel AC, Takeuchi O, Huang Z, Fisher JK, Zhou Z, Rubens J, Hertz C, Danial NN, Moskowitz MA, Korsmeyer SJ (2005) Cyclophilin D is a component of mitochondrial permeability transition and mediates neuronal cell death after focal cerebral ischemia. Proc Natl Acad Sci USA 102, 1200512010 .

[204] Gordon PH, Moore DH, Miller RG, Florence JM, Verheijde JL, Doorish C, Hilton JF, Spitalny GM, MacAuthur RB, Misumoto H, Neville HE, Biylan K, Mozaffar T, Belch JM, Ravits J, Bedlack RS, Graves MC, McCluskey LF, Barohn RJ, Tandan R (2007) Efficacy of minocycline in patients with amyotrophic lateral sclerosis: a phase III randomized trial. Lancet Neurol 6, 1045-1053.

[205] Wong M, Martin LJ (2010) Skeletal muscle-restricted expression of human SOD1 causes motor neuron degeneration in transgenic mice. Hum Mol Genet 19, 2284-2302. 